\title{
Use of Neutron Activation Analysis and Inductively Coupled Plasma Mass Spectrometry for the Determination of Trace Elements in Pediatric and Young Adult Prostate
}

\author{
Vladimir Zaichick $^{1^{*}}$, Sofia Zaichick ${ }^{1,2}$ \\ ${ }^{1}$ Radionuclide Diagnostics Department, Medical Radiological Research Centre, Obninsk, Russia \\ ${ }^{2}$ Department of Immunology and Microbiology, Northwestern University, Chicago, USA \\ Email: *vzaichick@gmail.com, s-zaichick@northwestern.edu
}

Received September 30, 2013; revised October 28, 2013; accepted November 14, 2013

Copyright (C) 2013 Vladimir Zaichick, Sofia Zaichick. This is an open access article distributed under the Creative Commons Attribution License, which permits unrestricted use, distribution, and reproduction in any medium, provided the original work is properly cited.

\begin{abstract}
The questions about the androgen control and the involvement of trace elements in prostatic reproductive function still remain unanswered. One valuable way to elucidate the situation is to compare the values for the prostatic mass fractions of trace elements in pre- and post-pubertal boys. The effect of age on the mass fraction of 54 trace elements in intact prostate of 50 apparently healthy 0 - 30 years old males was investigated by neutron activation analysis and inductively coupled plasma mass spectrometry. Mean values $(\mathrm{M} \pm \mathrm{SEM})$ for mass fraction (milligram per kilogram, on dry-weight basis) of trace elements were: Ag 0.062 \pm 0.008 , Al $80 \pm 18$, Au 0.0092 \pm 0.0024 , B 5.9 $\pm 3.5, \mathrm{Be} 0.0034 \pm 0.0009$, Bi $0.018 \pm 0.010$, Br $26 \pm 3, \mathrm{Cd} 0.26 \pm 0.05$, Ce $0.049 \pm 0.012$, Co $0.035 \pm 0.004$, Cr $0.49 \pm 0.07$, Cs $0.036 \pm 0.005, \mathrm{Dy}$ $0.0072 \pm 0.0018$, Er $0.0040 \pm 0.0011$, Fe $100 \pm 10$, Gd $0.0065 \pm 0.0018, \mathrm{Hg} 0.031 \pm 0.004$, Ho $0.0013 \pm 0.0004, \mathrm{La}$ $0.034 \pm 0.007$, Li $0.064 \pm 0.009$, Mn 1.69 \pm 0.15 , Mo $0.54 \pm 0.13, \mathrm{Nb} 0.013 \pm 0.004, \mathrm{Nd} 0.025 \pm 0.006, \mathrm{Ni} 4.1 \pm 0.6, \mathrm{~Pb}$ $1.3 \pm 0.2$, Pr 0.0058 \pm 0.0015 , Rb 14.5 \pm 0.8 , Sb 0.051 \pm 0.006 , Sc $0.013 \pm 0.002$, Se $0.54 \pm 0.03$, Sm $0.0055 \pm 0.0015$, Sn $0.22 \pm 0.05$, Tb $0.0012 \pm 0.0004$, Th $0.0076 \pm 0.0020$, Ti $2.8 \pm 0.5$, Tl $0.0032 \pm 0.0009$, Tm $0.00064 \pm 0.00017, \mathrm{U}$ $0.0025 \pm 0.0004, \mathrm{Y} 0.036 \pm 0.010, \mathrm{Yb} 0.0037 \pm 0.0012, \mathrm{Zn} 281 \pm 32$, and $\mathrm{Zr} 0.16 \pm 0.04$. The upper limit of mean mass fraction of As, Eu, Ga, Hf, Ir, Lu, Pd, Pt, Re, and Ta were: As $\leq 0.069$, Eu $\leq 0.0012$, Ga $\leq 0.071, \mathrm{Hf} \leq 0.049$, Ir $\leq$ $0.00054, \mathrm{Lu} \leq 0.00063, \mathrm{Pd} \leq 0.014, \mathrm{Pt} \leq 0.0029, \mathrm{Re} \leq 0.0048$, and $\mathrm{Ta} \leq 0.010$. This work revealed that there is a significant tendency for the mass fractions of $\mathrm{Cd}$, Se and $\mathrm{Zn}$ in the prostate tissue of healthy individuals to increase with age from the time of birth up to 30 years. It was also shown that high levels of $\mathrm{Al}, \mathrm{Au}, \mathrm{B}, \mathrm{Br}, \mathrm{Cr}, \mathrm{Ga}, \mathrm{Li}$, and $\mathrm{Ni}$ mass fraction in prostate tissue do not indicate a direct involvement of these elements in the reproductive function of prostate.
\end{abstract}

Keywords: NAA; ICP-MS; Trace Elements; Pediatric and Young Adult Prostate Glands

\section{Introduction}

The prostate gland is a vital part of the male reproductive system. It produces and excretes much of the liquid portion of semen (about $30 \%-35 \%$ of the semen ejaculate). The prostate mixes its fluids with those from the seminal vesicles to transport the sperm made in the testes.

The prostate of the adult male is known to accumulate high levels of some trace elements, including $\mathrm{Zn}$ [1]. The reason for the unusually high trace element content in normal prostate gland is not completely understood. The findings of low $\mathrm{Zn}$ level in pediatric prostate warranted

*Corresponding author. the conclusion that androgens are the major factors controlling the accumulation and maintenance of a high content of $\mathrm{Zn}$ in the prostate [2-5].

In our previous studies, the high mass fractions of $\mathrm{Zn}$ as well as some other trace elements were observed in prostate tissue of adult males when compared with those in nonprostatic soft tissues of the human body [1,5-8]. However, some questions about the androgen control and the involvement of trace elements in prostatic reproductive function still remain unanswered. One valuable way to elucidate the situation is to compare the values for the prostatic mass fractions of trace elements in pre-pubertal boys with those during early puberty, post-puberty and 
young adulthood.

The data on trace element mass fractions in pediatric prostate are apparently extremely limited $[2,3]$. There are few studies regarding trace element content in prostate of young adult males, using chemical techniques and instrumental methods [2,3,9-15]. However, the majority of these data are based on measurements of processed tissue. In many studies tissue samples are ashed before analysis. In other cases, prostate samples are treated with solvents (distilled water, ethanol etc) and then are dried at high temperature for many hours. There is evidence that certain quantities of trace elements are lost as a result of such treatment [16,17]. Moreover, only two of these studies employed quality control using certified reference materials (CRM) for determination of the trace element mass fractions $[14,15]$.

The primary purpose of this study was to investigate the possibilities of a non-destructive instrumental neutron activation analysis with high resolution spectrometry of long-lived radionuclides (NAA-LLR) and inductively coupled plasma mass spectrometry (ICP-MS) in the estimation of trace element contents in the samples of prostate tissue. The second aim was to determine reference values for trace element mass fractions in the intact prostate of subjects of different age groups from newborn to young adult males. The third aim was to evaluate the quality of the results making a comparison between NAALLR and ICP-MS data obtained. The final aim was to compare the trace element mass fractions in pre-pubertal boys (group 1) with those during early puberty, postpuberty and young adulthood (group 2).

All studies were approved by the Ethical Committee of the Medical Radiological Research Center, Obninsk.

\section{Materials and Methods}

\subsection{Samples}

Samples of the human prostate were obtained from randomly selected autopsy specimens of 50 males (EuropeanCaucasian) aged 0 day to 30 years. Age ranges for subjects were divided into two groups, with group 1, 0 - 13 years $(3.3 \pm 0.09$ years, $\mathrm{M} \pm \mathrm{SEM}, \mathrm{n}=29)$, and group 2 , 14 - 30 years $(24.4 \pm 1.0$ years, $\mathrm{M} \pm \mathrm{SEM}, \mathrm{n}=21)$. These age groups were selected to reflect the situation before puberty (group 1-infant, childhood, and peripubertal periods) and during and after puberty (group 2-adolescent and young adult periods). The available clinical data were reviewed for each subject. None of the subjects had a history of an intersex condition, endocrine disorder, neoplasm or other chronic disease that would affect the normal development of the prostate. None of the subjects was receiving medications known to affect prostate morphology and prostatic chemical element content. The typical causes of death in most of these patients included sudden infant death syndrome, acute pulmonary etiologies, and trauma. All prostate glands were divided (with an anterior-posterior cross-section) into two portions using a titanium scalpel. One tissue portion was reviewed by an anatomical pathologist while the other was used for the trace element content determination. Only the posterior part of the prostate, including the transitional, central, and peripheral zones, was investigated. A histological examination was used to control the age norm conformity as well as the absence of any microadenomatosis and/or latent cancer.

\subsection{Sample Preparation}

After the samples intended for trace element analysis were weighed, they were transferred to $-20^{\circ} \mathrm{C}$ and stored until the day of transportation in the Medical Radiological Research Center (MRRC), Obninsk. In the MRRC all samples were freeze-dried and homogenized. The pounded sample weighing about $50 \mathrm{mg}$ was used for chemical element measurement by instrumental NAA-LLR. The samples for NAA-LLR were wrapped separately in a high-purity aluminum foil washed with rectified alcohol beforehand and placed in a nitric acid-washed quartz ampoule.

The samples weighing about $100 \mathrm{mg}$ for ICP-MS were decomposed in autoclaves; $1.5 \mathrm{~mL}$ of concentrated $\mathrm{HNO}_{3}$ (nitric acid at $65 \%$, maximum $(\max )$ of $0.0000005 \% \mathrm{Hg}$; GR, ISO, Merck) and $0.3 \mathrm{~mL}$ of $\mathrm{H}_{2} \mathrm{O}_{2}$ (pure for analysis) were added to prostate tissue samples, placed in onechamber autoclaves (Ancon-AT2, Ltd., Russia) and then heated for $3 \mathrm{~h}$ at $160^{\circ} \mathrm{C}-200^{\circ} \mathrm{C}$. After autoclaving, they were cooled to room temperature and solutions from the decomposed samples were diluted with deionized water (up to $20 \mathrm{~mL}$ ) and transferred to plastic measuring bottles. Simultaneously, the same procedure was performed in autoclaves without tissue samples (only $\mathrm{HNO}_{3}+\mathrm{H}_{2} \mathrm{O}_{2}+$ deionized water), and the resultant solutions were used as control samples.

\subsection{Instrumentation and Methods}

\subsubsection{NAA-LLR Method}

A vertical channel of nuclear reactor was applied to determine the mass fractions of $\mathrm{Ag}, \mathrm{As}, \mathrm{Au}, \mathrm{Ba}, \mathrm{Br}, \mathrm{Cd}, \mathrm{Ce}$, $\mathrm{Co}, \mathrm{Cr}, \mathrm{Cs}, \mathrm{Eu}, \mathrm{Fe}, \mathrm{Gd}, \mathrm{Hf}, \mathrm{Hg}, \mathrm{La}, \mathrm{Lu}, \mathrm{Nd}, \mathrm{Rb}, \mathrm{Sb}, \mathrm{Sc}$, $\mathrm{Se}, \mathrm{Sm}, \mathrm{Sr}, \mathrm{Ta}, \mathrm{Tb}, \mathrm{Th}, \mathrm{U}, \mathrm{Yb}, \mathrm{Zn}$, and $\mathrm{Zr}$ by NAA-LLR. The quartz ampoule with prostate samples, standards, and certified reference materials was soldered, positioned in a transport aluminum container and exposed to a 24hour neutron irradiation in a vertical channel with a neutron flux of $1.3 \times 10^{13} \mathrm{n} \cdot \mathrm{cm}^{-2} \cdot \mathrm{s}^{-1}$. Ten days after irradiation samples were reweighed and repacked.

The samples were measured for period from 10 to 30 days after irradiation. The duration of measurements was 
from $20 \mathrm{~min}$ to 10 hours subject to pulse counting rate. The gamma spectrometer included the $100 \mathrm{~cm}^{3} \mathrm{Ge}(\mathrm{Li})$ detector and on-line computer-based MCA system. The spectrometer provided a resolution of $1.9 \mathrm{keV}$ on the ${ }^{60} \mathrm{Co} 1332 \mathrm{keV}$ line. The information of used radionuclides, gamma-energies, and other details of the analysis is presented in Table 1.

\subsubsection{ICP-MS Method}

Sample aliquots were used to determine the content of $\mathrm{Ag}, \mathrm{Al}, \mathrm{As}, \mathrm{Au}, \mathrm{B}, \mathrm{Be}, \mathrm{Bi}, \mathrm{Br}, \mathrm{Cd}, \mathrm{Ce}, \mathrm{Co}, \mathrm{Cr}, \mathrm{Cs}, \mathrm{Dy}, \mathrm{Er}$, $\mathrm{Eu}, \mathrm{Ga}, \mathrm{Gd}, \mathrm{Hf}, \mathrm{Hg}, \mathrm{Ho}$, Ir, La, Li, Lu, Mn, Mo, Nb, Nd, $\mathrm{Ni}, \mathrm{Pb}, \mathrm{Pd}, \mathrm{Pr}, \mathrm{Pt}, \mathrm{Rb}, \mathrm{Re}, \mathrm{Sb}, \mathrm{Se}, \mathrm{Sm}, \mathrm{Sn}, \mathrm{Ta}, \mathrm{Tb}, \mathrm{Te}, \mathrm{Th}$, $\mathrm{Ti}, \mathrm{Tl}, \mathrm{Tm}, \mathrm{U}, \mathrm{Y}, \mathrm{Yb}, \mathrm{Zn}$, and $\mathrm{Zr}$ by ICP-MS using an ICP-MS Thermo-Fisher "X-7" Spectrometer (Thermo Electron, USA). The measurements were made with the mass-spectrometer parameters shown in Table 2.

Table 1. Radionuclides, some of their characteristics and conditions of analysis" used for INAA-LLR prostate samples and certified reference materials.

\begin{tabular}{|c|c|c|c|}
\hline Element & Radionuclide & Half-life & $\gamma$-energy used (keV) \\
\hline $\mathrm{Ag}$ & ${ }^{110 \mathrm{~m}} \mathrm{Ag}$ & 250.0 days & 658,1384 \\
\hline As & ${ }^{76} \mathrm{As}$ & 1.12 days & 559 \\
\hline $\mathrm{Au}$ & ${ }^{198} \mathrm{Au}$ & 2.7 days & 412 \\
\hline $\mathrm{Ba}$ & ${ }^{131} \mathrm{Ba}$ & 11.52 days & $216,373,496$ \\
\hline $\mathrm{Br}$ & ${ }^{82} \mathrm{Br}$ & 1.47 days & $698,777,1044$ \\
\hline $\mathrm{Cd}$ & ${ }^{115} \mathrm{Cd}$ & 2.2 days & 336 \\
\hline $\mathrm{Ce}$ & ${ }^{141} \mathrm{Ce}$ & 32.5 days & 145 \\
\hline $\mathrm{Co}$ & ${ }^{60} \mathrm{Co}$ & 5.64 years & 1173,1332 \\
\hline $\mathrm{Cr}$ & ${ }^{51} \mathrm{Cr}$ & 27.8 days & 320 \\
\hline $\mathrm{Cs}$ & ${ }^{134} \mathrm{Cs}$ & 2.05 years & 796 \\
\hline $\mathrm{Eu}$ & ${ }^{152} \mathrm{Eu}$ & 13.6 years & 1408 \\
\hline $\mathrm{Fe}$ & ${ }^{59} \mathrm{Fe}$ & 45.6 days & 1099,1292 \\
\hline Gd & ${ }^{151} \mathrm{Gd}$ & 120 days & 154 \\
\hline Hf & ${ }^{181} \mathrm{Hf}$ & 42.4 days & 482 \\
\hline $\mathrm{Hg}$ & ${ }^{203} \mathrm{Hg}$ & 46.91 days & 279 \\
\hline $\mathrm{La}$ & ${ }^{140} \mathrm{La}$ & 1.68 days & $329,487,816,1595$ \\
\hline $\mathrm{Lu}$ & ${ }^{177} \mathrm{Lu}$ & 6.74 days & 208 \\
\hline $\mathrm{Nd}$ & ${ }^{147} \mathrm{Nd}$ & 11.02 days & 91 \\
\hline $\mathrm{Rb}$ & ${ }^{86} \mathrm{Rb}$ & 18.66 days & 1076 \\
\hline $\mathrm{Sb}$ & ${ }^{122} \mathrm{Sb}$ and ${ }^{124} \mathrm{Sb}$ & $2.74 \mathrm{~d}$ and 60.9 days & 564 and 1690 \\
\hline $\mathrm{Sc}$ & ${ }^{46} \mathrm{Sc}$ & 83.89 days & 889,1121 \\
\hline $\mathrm{Se}$ & ${ }^{75} \mathrm{Se}$ & 120.4 days & $136,265,401$ \\
\hline $\mathrm{Sm}$ & ${ }^{153} \mathrm{Sm}$ & 1.96 days & 103 \\
\hline $\mathrm{Sr}$ & ${ }^{85} \mathrm{Sr}$ & 64.8 days & 514 \\
\hline $\mathrm{Ta}$ & ${ }^{182} \mathrm{Ta}$ & 115 days & 1221 \\
\hline $\mathrm{Tb}$ & ${ }^{160} \mathrm{~Tb}$ & 72.3 days & 879,966 \\
\hline $\mathrm{Th}$ & ${ }^{233} \mathrm{~Pa}$ & 27.0 days & 312 \\
\hline $\mathrm{U}$ & ${ }^{239} \mathrm{~Np}$ & 2.36 days & 228,278 \\
\hline $\mathrm{Yb}$ & ${ }^{175} \mathrm{Yb}$ & 4.19 days & 396 \\
\hline $\mathrm{Zn}$ & ${ }^{65} \mathrm{Zn}$ & 245.7 days & 1115 \\
\hline $\mathrm{Zr}$ & ${ }^{95} \mathrm{Zr}$ & 35.0 days & 724,757 \\
\hline
\end{tabular}

*Irradiation time - 24 hours, decay-from 10 to 30 days, measurementfrom $20 \mathrm{~min}$ to 10 hours, sample-detector distance- from 0 to $5 \mathrm{~cm}$, detector shielding $-5 \mathrm{~cm}$ lead.
The element concentrations in aqueous solutions were determined by the quantitative method using multi elemental calibration solutions ICP-MS-68A and ICP-AM6-A produced by High-Purity Standards (Charleston, SC 29423, USA). Indium was used as an internal standard in all measurements. The next isotope(s) was/were measured and chosen for calculation, for each trace-element (see Table 3). If an element has several isotopes, the concentration of $\mathrm{Li}, \mathrm{B}, \mathrm{Ti}, \mathrm{Ni}, \mathrm{Zn}, \mathrm{Br}, \mathrm{Rb}, \mathrm{Mo}, \mathrm{Pd}, \mathrm{Ag}$, Cd, Sn, Sb, Te, Nd, Sm, Eu, Gd, Dy, ER, Yb, Hf, Re, Ir, $\mathrm{Pt}, \mathrm{Hg}, \mathrm{Tl}$, and $\mathrm{Pb}$ in a sample was calculated as the mean of the values measured for their different isotopes.

The detection limit (DL) was calculated as:

$$
\mathrm{DL}=\mathrm{Ci}+3 \times \mathrm{SD} \text {, }
$$

Table 2. The ICP-MS spectrometer parameters and the main parameters of mass-spectrum measurements.

\begin{tabular}{|c|c|c|c|}
\hline \multicolumn{4}{|c|}{ Spectrometer parameters } \\
\hline \multicolumn{2}{|c|}{ RF generator power } & \multicolumn{2}{|l|}{$1250 \mathrm{~W}$} \\
\hline \multicolumn{2}{|l|}{ Nebulizer } & \multicolumn{2}{|l|}{ Polycon } \\
\hline \multicolumn{2}{|l|}{ Spray chamber } & \multicolumn{2}{|c|}{ Cooled at $3^{\circ} \mathrm{C}$} \\
\hline \multicolumn{2}{|c|}{ Plasma gas flow rate } & \multicolumn{2}{|l|}{$12 \mathrm{~L} / \mathrm{min}$} \\
\hline \multicolumn{2}{|c|}{ Auxiliary flow rate } & \multicolumn{2}{|l|}{$0.9 \mathrm{~L} / \mathrm{min}$} \\
\hline \multicolumn{2}{|c|}{ Nebuliser flow rate } & \multicolumn{2}{|l|}{$0.9 \mathrm{~L} / \mathrm{min}$} \\
\hline \multicolumn{2}{|l|}{ Sample update } & \multicolumn{2}{|l|}{$0.8 \mathrm{~mL} / \mathrm{min}$} \\
\hline \multicolumn{2}{|l|}{ Resolution } & \multicolumn{2}{|c|}{0.8 atomic mass unit } \\
\hline \multicolumn{4}{|c|}{ Parameters of mass-spectrum measurements } \\
\hline \multicolumn{2}{|l|}{ Detector mode } & \multicolumn{2}{|c|}{ Double (pulse counting and analogous) } \\
\hline \multicolumn{2}{|l|}{ Scanning mode } & \multicolumn{2}{|c|}{ Survey scan and peak jumping } \\
\hline \multicolumn{2}{|c|}{ Setting for survey scan } & \multicolumn{2}{|c|}{ Setting for peak jumping } \\
\hline Number of runs & 10 & Sweeps & 25 \\
\hline Dwell time & $0.6 \mathrm{~ms}$ & Dwell time & $10 \mathrm{~ms}$ \\
\hline Channels per mass & 10 & Channels per mass & 1 \\
\hline Acquisition duration & $13.2 \mathrm{~s}$ & Acquisition duration & $34 \mathrm{~s}$ \\
\hline
\end{tabular}

Table 3. The isotope(s) used for determining chemical element contents by ICP-MS.

\begin{tabular}{cccccccc}
\hline $\mathrm{E}$ & Isotope(s) & $\mathrm{E}$ & Isotope(s) & $\mathrm{E}$ & Isotope(s) & $\mathrm{E}$ & Isotope(s) \\
\hline $\mathrm{Li}$ & 6,7 & $\mathrm{Rb}$ & 85 & $\mathrm{La}$ & 139 & $\mathrm{Lu}$ & 175 \\
$\mathrm{Be}$ & 9 & $\mathrm{Y}$ & 89 & $\mathrm{Ce}$ & 140 & $\mathrm{Hf}$ & 177,178 \\
$\mathrm{~B}$ & 10,11 & $\mathrm{Zr}$ & 90,91 & $\mathrm{Pr}$ & 141 & $\mathrm{Ta}$ & 181 \\
$\mathrm{Al}$ & 27 & $\mathrm{Nb}$ & 93 & $\mathrm{Nd}$ & 145,146 & $\mathrm{Re}$ & 185,187 \\
$\mathrm{Ti}$ & 47,50 & $\mathrm{Mo}$ & 95,98 & $\mathrm{Sm}$ & 147,149 & $\mathrm{Ir}$ & 191,193 \\
$\mathrm{Mn}$ & 55 & $\mathrm{Pd}$ & 104,105 & $\mathrm{Eu}$ & 151,153 & $\mathrm{Pt}$ & 194,195 \\
$\mathrm{Co}$ & 59 & $\mathrm{Ag}$ & 107,109 & $\mathrm{Gd}$ & 158,160 & $\mathrm{Au}$ & 197 \\
$\mathrm{Ni}$ & 60,62 & $\mathrm{Cd}$ & $111,112,114$ & $\mathrm{~Tb}$ & 159 & $\mathrm{Hg}$ & 201,202 \\
$\mathrm{Zn}$ & 66,68 & $\mathrm{In}$ & 115 & $\mathrm{Dy}$ & 162,163 & $\mathrm{Tl}$ & 203,205 \\
$\mathrm{Ga}$ & 71 & $\mathrm{Sn}$ & 118,120 & $\mathrm{Ho}$ & 165 & $\mathrm{~Pb}$ & 206,208 \\
$\mathrm{As}$ & 75 & $\mathrm{Sb}$ & 121,123 & $\mathrm{Er}$ & 167,168 & $\mathrm{Bi}$ & 209 \\
$\mathrm{Se}$ & 82 & $\mathrm{Te}$ & 125,126 & $\mathrm{Tm}$ & 169 & $\mathrm{Th}$ & 232 \\
$\mathrm{Br}$ & 79,81 & $\mathrm{Cs}$ & 133 & $\mathrm{Yb}$ & 173,174 & $\mathrm{U}$ & 238 \\
\hline
\end{tabular}

E: element. 
where $C_{i}$ is a mean value of the isotope content for measurements in control samples, and SD is a standard deviation of $C_{i}$ determination in control samples. For elements with several isotopes, the DL corresponded to that of the most abundant isotope.

The relative standard deviation (RSD) did not exceed 0.05 for elements with $C_{i}>5 \mathrm{DL}$ and did not exceed 0.20 for elements with $C_{\mathrm{i}}<5 \mathrm{DL}$.

\subsection{Standards and Certified Reference Materials}

For quality control, ten subsamples of the certified reference materials (CRM) IAEA H-4 Animal muscle and IAEA HH-1 Human hair from the International Atomic Energy Agency (IAEA), and also five sub-samples INCTSBF-4 Soya Bean Flour, INCT-TL-1 Tea Leaves and INCT-MPH-2 Mixed Polish Herbs from the Institute of Nuclear Chemistry and Technology (INCT, Warszawa, Poland) were analyzed simultaneously with the investigated prostate tissue samples. All samples of CRM were treated in the same way as the prostate tissue samples. Detailed results of this quality assurance program were presented in earlier publications $[1,7]$.

\subsection{Computer Programs and Statistic}

A dedicated computer program of NAA mode optimization was used [18].

Using the Microsoft Office Excel program to provide a summary of statistical results, the arithmetic mean, standard deviation, standard error of mean, minimum and maximum values were calculated for all the trace element mass fractions obtained. For elements investigated by two methods the mean of all results was used. The reliability of difference in the results between two age groups was evaluated by Student's parametric $t$-test. For the construction of "trace element mass fraction versus age" diagrams the Microsoft Office Excel program was also used.

\section{Results and Discussion}

\subsection{The Possibilities of NAA-LLR}

${ }^{203} \mathrm{Hg}$ has the only line of $279.19 \mathrm{keV}$ which coincides with the $279.54 \mathrm{keV}$ (25\%) line of ${ }^{75} \mathrm{Se}$. However, ${ }^{75} \mathrm{Se}$ has more intensive lines $136(56 \%)$ and $265 \mathrm{keV}(60 \%)$ (See Table 1). Using the information about ${ }^{75} \mathrm{Se}$ lines $136 \mathrm{keV}$ and $265 \mathrm{keV}$, the intensity of $279.54 \mathrm{keV}$ line was calculated and the interference with ${ }^{203} \mathrm{Hg} 279.19$ $\mathrm{keV}$ line was under control.

Thus, the instrumental neutron activation analysis with high resolution spectrometry of long-lived radionuclides allowed determine the mass fractions of 10 chemical elements (Ag, Co, Cr, Fe, Hg, Rb, Sb, Sc, Se, and $\mathrm{Zn}$ ) in the tissue samples of pediatric and nonhyperplastic young adult prostate glands. Mean values $(\mathrm{M} \pm \mathrm{SEM})$ for mass fraction (milligram per kilogram, on dry-weight basis) of chemical elements between ages 0 - 30 years were: $\mathrm{Ag}$ $0.071 \pm 0.009, \mathrm{Co}-0.035 \pm 0.004, \mathrm{Cr}-0.47 \pm 0.07$, $\mathrm{Fe}-100 \pm 10, \mathrm{Hg}-0.026 \pm 0.002, \mathrm{Rb}-12.6 \pm 0.8, \mathrm{Sb}-$ $0.058 \pm 0.007, \mathrm{Sc}-0.013 \pm 0.002, \mathrm{Se}-0.48 \pm 0.03$, and $\mathrm{Zn}-273 \pm 31$.

\subsection{The Possibilities of ICP-MS}

The inductively coupled plasma mass spectrometry allowed measurement the mass fractions or an upper limit of mass fractions of 51 chemical elements in the tissue samples of pediatric and nonhyperplastic young adult prostate glands. Mean values for mass fraction of 41 chemical elements between ages 0 - 30 years were: $\mathrm{Ag}$ $0.052 \pm 0.007, \mathrm{Al}-79.7 \pm 18.2, \mathrm{Au}-0.0092 \pm 0.0024$ $\mathrm{B}-5.9 \pm 3.5, \mathrm{Be}-0.0034 \pm 0.0009, \mathrm{Bi}-0.018 \pm 0.010$, $\mathrm{Br}-26.3 \pm 3.1, \mathrm{Cd}-0.26 \pm 0.05, \mathrm{Ce}-0.049 \pm 0.012$, $\mathrm{Co}-0.036 \pm 0.004, \mathrm{Cr}-0.53 \pm 0.08, \mathrm{Cs}-0.036 \pm 0.005$, $\mathrm{Dy}-0.0072 \pm 0.0018, \mathrm{Er}-0.0040 \pm 0.0011, \mathrm{Gd}-$ $0.0065 \pm 0.0018, \mathrm{Hg}-0.034 \pm 0.005, \mathrm{Ho}-0.0013 \pm$ $0.0004, \mathrm{La}-0.034 \pm 0.007, \mathrm{Li}-0.064 \pm 0.009, \mathrm{Mn}-$ $1.69 \pm 0.15, \mathrm{Mo}-0.54 \pm 0.13, \mathrm{Nb}-0.013 \pm 0.004, \mathrm{Nd}-$ $0.025 \pm 0.006, \mathrm{Ni}-4.08 \pm 0.56, \mathrm{~Pb}-1.30 \pm 0.24, \mathrm{Pr}-$ $0.0058 \pm 0.0015, \mathrm{Rb}-16.2 \pm 0.8, \mathrm{Sb}-0.044 \pm 0.007$, $\mathrm{Se}-0.59 \pm 0.04, \mathrm{Sm}-0.0055 \pm 0.0015, \mathrm{Sn}-0.22 \pm 0.05$, $\mathrm{Tb}-0.0012 \pm 0.0004, \mathrm{Th}-0.0076 \pm 0.0020, \mathrm{Ti}-2.79 \pm$ $0.53, \mathrm{Tl}-0.0032 \pm 0.0009, \mathrm{Tm}-0.00064 \pm 0.00017$, $\mathrm{U}-0.0025 \pm 0.0004, \mathrm{Y}-0.036 \pm 0.010, \mathrm{Yb}-0.0037 \pm$ $0.0012, \mathrm{Zn}-277 \pm 33$, and $\mathrm{Zr}-0.16 \pm 0.04$. The upper limits of mass fraction of 10 chemical elements in the same samples were: $\mathrm{As} \leq 0.069, \mathrm{Eu} \leq 0.0012, \mathrm{Ga} \leq 0.071$, Hf $\leq 0.049, \mathrm{Ir} \leq 0.00054, \mathrm{Lu} \leq 0.00063, \mathrm{Pd} \leq 0.014, \mathrm{Pt} \leq$ $0.0029, \mathrm{Re} \leq 0.0048$, and $\mathrm{Ta} \leq 0.010$.

\subsection{Precision and Accuracy}

The use of two analytical methods allowed us to estimate the mass fractions of 54 trace elements in human prostate tissue. Good agreement was found between the mean values of the $\mathrm{Ag}, \mathrm{As}, \mathrm{Au}, \mathrm{Br}, \mathrm{Cd}, \mathrm{Ce}, \mathrm{Co}, \mathrm{Cr}, \mathrm{Cs}, \mathrm{Eu}, \mathrm{Gd}$, $\mathrm{Hf}, \mathrm{Hg}, \mathrm{La}, \mathrm{Lu}, \mathrm{Nd}, \mathrm{Rb}, \mathrm{Sb}, \mathrm{Se}, \mathrm{Sm}, \mathrm{Ta}, \mathrm{Tb}, \mathrm{Th}, \mathrm{U}, \mathrm{Yb}$, $\mathrm{Zn}$, and $\mathrm{Zr}$ mass fractions determined by NAA-LLR and ICP-MS (Table 4) indicating complete digestion of the prostate tissue samples (for ICP-MS techniques) and correctness of all results obtained by the two methods. The fact that the elemental mass fractions (mean \pm SD) of the certified reference materials obtained in the present work were in good agreement with the certified values and within the corresponding 95\% confidence intervals $[1,7]$ suggests an acceptable accuracy of the measurements performed on in prostate tissue samples. 
Table 4. Comparison of mean values $(M \pm S E M)$ trace element mass fractions (in milligrams per kilogram dry-mass basis) in the nonhyperplastic prostate gland of males between ages 0 - 30 years obtained by both NAA-LL and ICP-MS methods.

\begin{tabular}{|c|c|c|c|}
\hline Element & NAA-LLR (1) & ICP-MS (2) & $\Delta^{*}, \%$ \\
\hline $\mathrm{Ag}$ & $0.071 \pm 0.009$ & $0.052 \pm 0.007$ & 26.8 \\
\hline As & $<0.1$ & $\leq 0.069$ & - \\
\hline $\mathrm{Au}$ & $<0.01$ & $0.0092 \pm 0.0024$ & - \\
\hline $\mathrm{Br}$ & $<50$ & $26.3 \pm 3.1$ & - \\
\hline $\mathrm{Cd}$ & $<2.0$ & $0.26 \pm 0.05$ & - \\
\hline $\mathrm{Ce}$ & $<0.05$ & $0.049 \pm 0.012$ & - \\
\hline Co & $0.035 \pm 0.004$ & $0.036 \pm 0.004$ & -2.86 \\
\hline $\mathrm{Cr}$ & $0.47 \pm 0.07$ & $0.53 \pm 0.08$ & -12.8 \\
\hline Cs & $<0.04$ & $0.036 \pm 0.005$ & - \\
\hline $\mathrm{Eu}$ & $<0.001$ & $\leq 0.0012$ & - \\
\hline Gd & $<0.25$ & $0.0065 \pm 0.0018$ & - \\
\hline Hf & $<0.05$ & $\leq 0.049$ & - \\
\hline $\mathrm{Hg}$ & $0.026 \pm 0.002$ & $0.031 \pm 0.004$ & -19.2 \\
\hline $\mathrm{La}$ & $<0.05$ & $0.034 \pm 0.007$ & - \\
\hline $\mathrm{Lu}$ & $<0.003$ & $\leq 0.00063$ & - \\
\hline $\mathrm{Nd}$ & $<0.1$ & $0.025 \pm 0.006$ & - \\
\hline $\mathrm{Rb}$ & $12.6 \pm 0.8$ & $16.2 \pm 0.8$ & -28.6 \\
\hline $\mathrm{Sb}$ & $0.057 \pm 0.007$ & $0.044 \pm 0.007$ & 22.8 \\
\hline $\mathrm{Se}$ & $0.48 \pm 0.03$ & $0.59 \pm 0.04$ & -22.9 \\
\hline $\mathrm{Sm}$ & $<0.01$ & $0.0055 \pm 0.0015$ & - \\
\hline Ta & $<0.1$ & $\leq 0.010$ & - \\
\hline $\mathrm{Tb}$ & $<0.03$ & $0.0012 \pm 0.0004$ & - \\
\hline Th & $<0.05$ & $0.0076 \pm 0.0020$ & - \\
\hline $\mathrm{U}$ & $<0.07$ & $0.0025 \pm 0.0004$ & - \\
\hline $\mathrm{Yb}$ & $<0.03$ & $0.0037 \pm 0.0012$ & - \\
\hline $\mathrm{Zn}$ & $273 \pm 31$ & $277 \pm 33$ & -1.5 \\
\hline $\mathrm{Zr}$ & $<1.0$ & $0.16 \pm 0.04$ & - \\
\hline
\end{tabular}

$\mathrm{M}$ arithmetic mean, SEM standard error of mean; ${ }^{*} \Delta=[(\mathrm{M} 1-\mathrm{M} 2) / \mathrm{M} 1] \times$ $100 \%$.

\subsection{Contents of Chemical Elements}

The mean values of mass fractions and all selected statistical parameters were calculated for $43(\mathrm{Ag}, \mathrm{Al}, \mathrm{Au}, \mathrm{B}$, $\mathrm{Be}, \mathrm{Bi}, \mathrm{Br}, \mathrm{Cd}, \mathrm{Ce}, \mathrm{Co}, \mathrm{Cr}, \mathrm{Cs}, \mathrm{Dy}, \mathrm{Er}, \mathrm{Fe}, \mathrm{Gd}, \mathrm{Hg}, \mathrm{Ho}$, $\mathrm{La}, \mathrm{Li}, \mathrm{Mn}, \mathrm{Mo}, \mathrm{Nb}, \mathrm{Nd}, \mathrm{Ni}, \mathrm{Pb}, \mathrm{Pr}, \mathrm{Rb}, \mathrm{Sb}, \mathrm{Sc}, \mathrm{Se}, \mathrm{Sm}$, $\mathrm{Sn}, \mathrm{Tb}, \mathrm{Th}, \mathrm{Ti}, \mathrm{Tl}, \mathrm{Tm}, \mathrm{U}, \mathrm{Y}, \mathrm{Yb}, \mathrm{Zn}$, and $\mathrm{Zr}$ ) trace eleents in the nonhyperplastic prostate gland of males in two age groups 0 - 13 and 14 - 30 years (Tables 5 and $\mathbf{6}$, respectively). The contents of these elements were measured in all or a major portion of prostate tissue samples. The As, Eu, Ga, Hf, Ir, Lu, Pd, Pt, Re, and Ta mass fractions were determined in a few samples. The possible upper limit of the mean $(\leq \mathrm{M})$ for these trace elements was calculated as the average mass fraction, using the value of the detection limit (DL) instead of the individual value when the latter was found to be below the DL:
Table 5. Basic statistical parameters of trace element mass fraction (in milligrams per kilogram dry-mass basis) in the nonhyperplastic prostate gland of males between ages 0 - 13 years (before puberty - the age group 1).

\begin{tabular}{|c|c|c|c|c|c|}
\hline$E$ & $\mathrm{M}$ & SD & SEM & Min & Max \\
\hline $\mathrm{Ag}$ & 0.0767 & 0.0507 & 0.0106 & 0.0149 & 0.209 \\
\hline $\mathrm{Al}$ & 119 & 123 & 32 & 16.2 & 478 \\
\hline As & $\leq 0.123$ & - & - & $<0.01$ & 0.830 \\
\hline $\mathrm{Au}$ & 0.0145 & 0.0171 & 0.0044 & 0.000900 & 0.0636 \\
\hline B & 9.4 & 22.2 & 5.9 & 0.410 & 83.4 \\
\hline $\mathrm{Be}$ & 0.0059 & 0.0065 & 0.0017 & 0.000700 & 0.0200 \\
\hline $\mathrm{Bi}$ & 0.032 & 0.070 & 0.019 & 0.00210 & 0.270 \\
\hline $\mathrm{Br}$ & 30.0 & 19.1 & 4.5 & 8.30 & 81.1 \\
\hline $\mathrm{Cd}$ & 0.085 & 0.051 & 0.013 & 0.0240 & 0.230 \\
\hline $\mathrm{Ce}$ & 0.073 & 0.084 & 0.022 & 0.0120 & 0.290 \\
\hline $\mathrm{Co}$ & 0.0440 & 0.0301 & 0.0061 & 0.00360 & 0.108 \\
\hline $\mathrm{Cr}$ & 0.69 & 0.51 & 0.11 & 0.0100 & 1.80 \\
\hline $\mathrm{Cs}$ & 0.0365 & 0.0357 & 0.0092 & 0.00900 & 0.160 \\
\hline Dy & 0.0108 & 0.0125 & 0.0032 & 0.00110 & 0.0500 \\
\hline $\mathrm{Er}$ & 0.0060 & 0.0077 & 0.0020 & 0.000520 & 0.0300 \\
\hline $\mathrm{Eu}$ & 0.00188 & 0.00195 & 0.00050 & 0.000390 & 0.00740 \\
\hline $\mathrm{Fe}$ & 120 & 86 & 16 & 10.0 & 335 \\
\hline $\mathrm{Ga}$ & 0.076 & 0.058 & 0.015 & 0.0200 & 0.200 \\
\hline $\mathrm{Gd}$ & 0.0099 & 0.0128 & 0.0033 & 0.00130 & 0.0500 \\
\hline $\mathrm{Hf}$ & 0.083 & 0.096 & 0.025 & 0.0130 & 0.270 \\
\hline $\mathrm{Hg}$ & 0.0345 & 0.0360 & 0.0079 & 0.00290 & 0.170 \\
\hline Но & 0.00191 & 0.00265 & 0.00071 & 0.000180 & 0.0100 \\
\hline Ir & $\leq 0.00071$ & - & - & $<0.0002$ & 0.0030 \\
\hline $\mathrm{La}$ & 0.049 & 0.044 & 0.011 & 0.00900 & 0.130 \\
\hline $\mathrm{Li}$ & 0.085 & 0.058 & 0.015 & 0.0150 & 0.170 \\
\hline $\mathrm{Lu}$ & 0.00096 & 0.00103 & 0.00027 & 0.0000700 & 0.00400 \\
\hline $\mathrm{Mn}$ & 1.90 & 1.07 & 0.27 & 0.660 & 3.90 \\
\hline Mo & 0.79 & 0.91 & 0.24 & 0.140 & 3.20 \\
\hline $\mathrm{Nb}$ & 0.0225 & 0.0251 & 0.0065 & 0.00400 & 0.0800 \\
\hline $\mathrm{Nd}$ & 0.038 & 0.043 & 0.011 & 0.00490 & 0.160 \\
\hline $\mathrm{Ni}$ & 4.50 & 3.85 & 1.03 & 0.600 & 12.0 \\
\hline $\mathrm{Pb}$ & 1.81 & 1.47 & 0.38 & 0.190 & 6.30 \\
\hline $\mathrm{Pd}$ & $\leq 0.019$ & - & - & $<0.005$ & 0.100 \\
\hline $\operatorname{Pr}$ & 0.0085 & 0.0101 & 0.0026 & 0.000700 & 0.0360 \\
\hline $\mathrm{Pt}$ & 0.00513 & 0.00376 & 0.00097 & 0.000800 & 0.0110 \\
\hline $\mathrm{Rb}$ & 15.1 & 6.2 & 1.2 & 4.80 & 25.4 \\
\hline $\mathrm{Re}$ & 0.0086 & 0.0051 & 0.0014 & 0.00150 & 0.0170 \\
\hline $\mathrm{Sb}$ & 0.057 & 0.048 & 0.010 & 0.00630 & 0.175 \\
\hline $\mathrm{Sc}$ & 0.0162 & 0.0124 & 0.0028 & 0.00110 & 0.0525 \\
\hline $\mathrm{Se}$ & 0.452 & 0.202 & 0.040 & 0.0500 & 1.06 \\
\hline $\mathrm{Sm}$ & 0.0084 & 0.0105 & 0.0027 & 0.00110 & 0.0410 \\
\hline $\mathrm{Sn}$ & 0.342 & 0.318 & 0.082 & 0.0590 & 1.00 \\
\hline $\mathrm{Ta}$ & $\leq 0.016$ & - & - & $<0.004$ & 0.080 \\
\hline $\mathrm{Tb}$ & 0.00187 & 0.00276 & 0.00071 & 0.000170 & 0.0110 \\
\hline $\mathrm{Te}$ & $<0.003$ & - & - & $<0.003$ & - \\
\hline Th & 0.0128 & 0.0134 & 0.0034 & 0.00120 & 0.0400 \\
\hline $\mathrm{Ti}^{*}$ & 4.14 & 3.38 & 0.87 & 0.400 & 10.4 \\
\hline $\mathrm{Tl}$ & 0.0049 & 0.0063 & 0.0016 & 0.00100 & 0.0240 \\
\hline $\mathrm{Tm}$ & 0.00097 & 0.00116 & 0.00030 & 0.000100 & 0.00460 \\
\hline U & 0.00338 & 0.00244 & 0.00070 & 0.000700 & 0.00900 \\
\hline Y & 0.055 & 0.068 & 0.018 & 0.00400 & 0.250 \\
\hline $\mathrm{Yb}$ & 0.0056 & 0.0082 & 0.0022 & 0.000560 & 0.0320 \\
\hline $\mathrm{Zn}$ & 155 & 167 & 31 & 61.8 & 981 \\
\hline $\mathrm{Zr}$ & 0.247 & 0.244 & 0.063 & 0.0260 & 0.760 \\
\hline
\end{tabular}

E: Element, M: arithmetic mean, SD: standard deviation, SEM: standard error of mean, Min: minimum value, Max: maximum value; ${ }^{*}$ Titanium tools were used for sampling and sample preparation. 
Table 6. Basic statistical parameters of trace element mass fraction (in milligrams per kilogram dry-mass basis) in the nonhyperplastic prostate gland of males between ages 14 30 years (puberty and postpuberty-the age group 2).

\begin{tabular}{|c|c|c|c|c|c|}
\hline$E$ & $M$ & SD & SEM & Min & Max \\
\hline $\mathrm{Ag}$ & 0.0421 & 0.0396 & 0.0096 & 0.00800 & 0.124 \\
\hline $\mathrm{Al}$ & 37.8 & 28.5 & 7.6 & 6.80 & 115 \\
\hline As & $\leq 0.012$ & - & - & $<0.01$ & 0.020 \\
\hline $\mathrm{Au}$ & 0.0040 & 0.0043 & 0.0011 & 0.00100 & 0.0149 \\
\hline B & 1.02 & 0.83 & 0.26 & 0.400 & 3.20 \\
\hline $\mathrm{Be}$ & 0.00110 & 0.00051 & 0.00013 & 0.000700 & 0.00260 \\
\hline $\mathrm{Bi}$ & 0.00404 & 0.00190 & 0.00053 & 0.00180 & 0.00750 \\
\hline $\mathrm{Br}$ & 22.4 & 16.6 & 4.0 & 3.00 & 48.6 \\
\hline $\mathrm{Cd}$ & 0.441 & 0.270 & 0.072 & 0.0800 & 1.00 \\
\hline $\mathrm{Ce}$ & 0.0241 & 0.0217 & 0.0058 & 0.00600 & 0.0750 \\
\hline Co & 0.0248 & 0.0091 & 0.0020 & 0.0135 & 0.0454 \\
\hline $\mathrm{Cr}$ & 0.246 & 0.183 & 0.042 & 0.0470 & 0.687 \\
\hline Cs & 0.0360 & 0.0111 & 0.0030 & 0.0240 & 0.0550 \\
\hline Dy & 0.00326 & 0.00338 & 0.00090 & 0.000400 & 0.0120 \\
\hline $\mathrm{Er}$ & 0.00186 & 0.00214 & 0.00057 & 0.000160 & 0.00710 \\
\hline $\mathrm{Eu}$ & $\leq 0.00054$ & - & - & $<0.0004$ & 0.0015 \\
\hline $\mathrm{Fe}$ & 72.3 & 26.0 & 5.8 & 38.0 & 127 \\
\hline $\mathrm{Ga}$ & $\leq 0.066$ & - & - & $<0.02$ & 0.49 \\
\hline Gd & 0.00284 & 0.00290 & 0.00078 & 0.000300 & 0.0100 \\
\hline $\mathrm{Hf}$ & $\leq 0.013$ & - & - & $<0.01$ & 0.035 \\
\hline $\mathrm{Hg}$ & 0.0283 & 0.0127 & 0.0028 & 0.0162 & 0.0713 \\
\hline Ho & 0.00060 & 0.00065 & 0.00017 & 0.0000900 & 0.00210 \\
\hline Ir & $\leq 0.00035$ & - & - & $<0.0002$ & 0.0010 \\
\hline $\mathrm{La}$ & 0.0172 & 0.0116 & 0.0032 & 0.00800 & 0.0490 \\
\hline $\mathrm{Li}$ & 0.0424 & 0.0259 & 0.0069 & 0.0150 & 0.0970 \\
\hline $\mathrm{Lu}$ & $\leq 0.00028$ & - & - & $<0.00007$ & 0.0011 \\
\hline $\mathrm{Mn}$ & 1.48 & 0.48 & 0.12 & 0.800 & 2.50 \\
\hline Mo & 0.279 & 0.133 & 0.035 & 0.110 & 0.580 \\
\hline $\mathrm{Nb}$ & 0.00329 & 0.00329 & 0.00088 & 0.00100 & 0.0110 \\
\hline $\mathrm{Nd}$ & 0.0124 & 0.0107 & 0.0029 & 0.00400 & 0.0350 \\
\hline $\mathrm{Ni}$ & 3.65 & 1.78 & 0.48 & 0.200 & 6.80 \\
\hline $\mathrm{Pb}$ & 0.75 & 0.88 & 0.24 & 0.250 & 3.72 \\
\hline $\mathrm{Pd}$ & $\leq 0.0072$ & - & - & $<0.005)$ & 0.010 \\
\hline $\operatorname{Pr}$ & 0.00299 & 0.00279 & 0.00075 & 0.000700 & 0.00940 \\
\hline $\mathrm{Pt}$ & $\leq 0.00054$ & - & - & $<0.0005$ & 0.0010 \\
\hline $\mathrm{Rb}$ & 13.7 & 3.54 & 0.79 & 7.70 & 24.0 \\
\hline $\mathrm{Re}$ & $\leq 0.00099$ & - & - & $<0.0009$ & 0.0010 \\
\hline $\mathrm{Sb}$ & 0.0432 & 0.0231 & 0.0052 & 0.00900 & 0.0924 \\
\hline $\mathrm{Sc}$ & 0.0087 & 0.0051 & 0.0012 & 0.00240 & 0.0207 \\
\hline $\mathrm{Se}$ & 0.644 & 0.203 & 0.045 & 0.372 & 1.11 \\
\hline $\mathrm{Sm}$ & 0.00246 & 0.00246 & 0.00066 & 0.000500 & 0.00790 \\
\hline $\mathrm{Sn}$ & 0.096 & 0.095 & 0.025 & 0.0300 & 0.300 \\
\hline $\mathrm{Ta}$ & $\leq 0.0044$ & - & - & $<0.004$ & 0.0090 \\
\hline $\mathrm{Tb}$ & 0.00041 & 0.00057 & 0.00015 & 0.000070 & 0.00210 \\
\hline $\mathrm{Te}$ & $<0.003$ & - & - & $<0.003)$ & - \\
\hline Th & 0.00210 & 0.00212 & 0.00057 & 0.000500 & 0.00850 \\
\hline $\mathrm{Ti}^{*}$ & 1.35 & 0.93 & 0.25 & 0.700 & 3.46 \\
\hline $\mathrm{Tl}$ & 0.00140 & 0.00049 & 0.00013 & 0.000200 & 0.00240 \\
\hline $\mathrm{Tm}$ & 0.000299 & 0.000345 & 0.000092 & 0.0000500 & 0.00120 \\
\hline U & 0.00164 & 0.00106 & 0.00028 & 0.000540 & 0.00406 \\
\hline $\mathrm{Y}$ & 0.0159 & 0.0199 & 0.0055 & 0.00200 & 0.0710 \\
\hline $\mathrm{Yb}$ & 0.00175 & 0.00214 & 0.00057 & 0.000100 & 0.00690 \\
\hline $\mathrm{Zn}$ & 456 & 188 & 41 & 155 & 869 \\
\hline $\mathrm{Zr}$ & 0.055 & 0.073 & 0.020 & 0.0100 & 0.250 \\
\hline
\end{tabular}

E: Element, M: arithmetic mean, SD: standard deviation, SEM: standard error of mean, Min: minimum value, Max: maximum value; ${ }^{*}$ Titanium tools were used for sampling and sample preparation.

$$
\leq M=\left(\sum_{i}^{n_{i}} C_{i}+D L \cdot n_{j}\right) / n,
$$

where $C_{i}$ is the individual value of the trace-element mass fraction in sample $-i, n_{i}$ is number of samples with mass fraction higher than the DL, $n_{j}$ is number of samples with mass fraction lower than the DL, and $n=n_{i}+n_{j}$ is number of samples that were investigated.

Generally, the mass fractions of $\mathrm{Te}$ in prostate tissue samples were lower than the corresponding DL of ICPMS (0.003 milligrams per kilogram on a dry mass basis).

The level of $\mathrm{Zn}$ in prostate is much higher than contents of other trace element: around an order of magnitude $-\mathrm{Fe}$; two orders of magnitude $-\mathrm{Rb}$; three orders of magnitude $-\mathrm{Cr}$, and $\mathrm{Se}$; four orders of magnitude $-\mathrm{Ag}$, $\mathrm{Co}, \mathrm{Hg}, \mathrm{Sb}$, and $\mathrm{Sc}$.

\subsection{Comparison with Published Data}

The means of $\mathrm{Fe}$ and $\mathrm{Zn}$ mass fractions obtained for prostate tissue of infant and children (age group 1) as shown in Table 5, agree well with range of mean values reported by Heinzsch et al. (1970) and Leissner et al. (1980) [2,3]. No published data referring to other trace element mass fractions in pediatric prostate glands were found.

The obtained values for $\mathrm{Ag}, \mathrm{As}, \mathrm{Cd}, \mathrm{Cr}, \mathrm{Cs}, \mathrm{Fe}, \mathrm{Mn}$, $\mathrm{Mo}, \mathrm{Ni}, \mathrm{Pb}, \mathrm{Rb}, \mathrm{Se}, \mathrm{Ti}, \mathrm{Tl}$, and $\mathrm{Zn}$ mass fractions in young adult nonhyperplastic prostate glands as shown in Table 7, agree well with median or range of means cited by other researches for the normal prostate tissue of adult males, including samples received from persons who died from different diseases [14,15,19-34]. A number of values for chemical element mass fractions were not expressed on a dry weight basis by the authors of the cited references. However, we calculated these values using published data for water- $80 \%$ [35] and ash $-1.0 \%$ on wet weight basis [11] contents in prostate of adult men. The means of $\mathrm{Al}, \mathrm{B}$, and $\mathrm{Br}$ are somewhat higher and of $\mathrm{Bi}$ and $\mathrm{Sn}$ are somewhat lower than the maximum and minimum mean value of previously reported data, respectively. The means of this work for $\mathrm{Au}, \mathrm{Hg}, \mathrm{Sb}, \mathrm{Te}, \mathrm{U}$, and $\mathrm{Y}$ is from one to six orders of magnitude lower, than previously reported results. No published data referring to Be, Ce, Dy, Er, Eu, Ga, Gd, Hf, Ho, Ir, La, Li, Lu, Nb, $\mathrm{Nd}, \mathrm{Pd}, \mathrm{Pr}, \mathrm{Pt}, \mathrm{Re}, \mathrm{Sc}, \mathrm{Sm}, \mathrm{Ta}, \mathrm{Tb}, \mathrm{Th}, \mathrm{Tm}, \mathrm{Yb}$, and $\mathrm{Zr}$ mass fractions in prostate gland of adult men were found.

\subsection{Age-Related Changes}

In the histologically normal prostates, we have observed a significant decrease in mass fraction of the $\mathrm{Ag}, \mathrm{Al}, \mathrm{Au}$, $\mathrm{B}, \mathrm{Be}, \mathrm{Ce}, \mathrm{Co}, \mathrm{Cr}, \mathrm{Dy}, \mathrm{Fe}, \mathrm{Gd}, \mathrm{La}, \mathrm{Li} \mathrm{Mo}, \mathrm{Nb}, \mathrm{Nd}, \mathrm{Pb}, \mathrm{Sc}$, $\mathrm{Se}, \mathrm{Sm}, \mathrm{Sn}, \mathrm{Th}, \mathrm{Ti}, \mathrm{Tl}, \mathrm{Tm}, \mathrm{U}$, and $\mathrm{Zr}$ with age from the time of birth up to 30 years, accompanied by an increase 
Table 7. Median, minimum and maximum value of means of trace element mass fractions (in milligrams per kilogram dry-mass basis) in prostate tissue of adult males according to data from the literature in comparison with this work results (prostate gland of young adults, 20 - 30 years).

\begin{tabular}{|c|c|c|c|c|}
\hline \multirow[b]{2}{*}{$\mathrm{E}$} & \multicolumn{3}{|c|}{ Published data [Reference] } & \multirow{2}{*}{$\begin{array}{c}\text { This work } \\
\mathrm{M} \pm \mathrm{SD} \\
\mathrm{n}=16\end{array}$} \\
\hline & $\begin{array}{c}\text { Median } \\
\left(\mathrm{n}^{\mathrm{a}}\right)\end{array}$ & $\begin{array}{c}\text { Minimum } \\
M \pm S D,\left(n^{b}\right)\end{array}$ & $\begin{array}{c}\text { Maximum } \\
\mathrm{M} \pm \mathrm{SD},\left(\mathrm{n}^{\mathrm{b}}\right)\end{array}$ & \\
\hline $\mathrm{Ag}$ & $\leq 0.1(2)$ & $<0.05$ (48) [19] & $0.2(7)[20]$ & $0.06 \pm 0.05$ \\
\hline $\mathrm{Al}$ & $27.7(3)$ & $13 \pm 66(50)[19]$ & $47(9)[21]$ & $80 \pm 98$ \\
\hline As & $0.045(1)$ & $0.05(10)[22]$ & $0.05(10)[22]$ & $\leq 0.069$ \\
\hline $\mathrm{Au}$ & $\leq 1.0(2)$ & $<0.7$ (48) [19] & $1.3(7)[20]$ & $0.009 \pm 0.013$ \\
\hline $\mathrm{B}$ & $1.2(2)$ & $<0.47(50)[19]$ & $1.0(1)[20]$ & $5.9 \pm 17.2$ \\
\hline $\mathrm{Be}$ & - & - & - & $0.003 \pm 0.005$ \\
\hline $\mathrm{Bi}$ & $<0.09$ (1) & $<0.09(50)[19]$ & $<0.09$ (50) [19] & $0.018 \pm 0.052$ \\
\hline $\mathrm{Br}$ & $14.5(2)$ & $12 \pm 8(4)[23]$ & $17(12)[24]$ & $26 \pm 18$ \\
\hline $\mathrm{Cd}$ & $0.79(16)$ & $0.06(129)[15]$ & $427(55)[25]$ & $0.26 \pm 0.26$ \\
\hline $\mathrm{Ce}$ & - & - & - & $0.049 \pm 0.066$ \\
\hline Co & $0.55(3)$ & $<0.09(50)[19]$ & $12(9)[21]$ & $0.035 \pm 0.025$ \\
\hline $\mathrm{Cr}$ & $0.56(3)$ & $0.042(50)[19]$ & $1.4(8)[20]$ & $0.49 \pm 0.45$ \\
\hline Cs & $<0.47(2)$ & $0.06(6)[26]$ & $2.8(12)[24]$ & $0.036 \pm 0.026$ \\
\hline Dy & - & - & - & $0.008 \pm 0.010$ \\
\hline $\mathrm{Er}$ & - & - & - & $0.004 \pm 0.006$ \\
\hline $\mathrm{Eu}$ & - & - & - & $\leq 0.0012$ \\
\hline $\mathrm{Fe}$ & $150(19)$ & $5.71(5)$ [27] & $1040(10)[28]$ & $100 \pm 71$ \\
\hline $\mathrm{Ga}$ & - & - & - & $\leq 0.071$ \\
\hline $\mathrm{Gd}$ & - & - & - & $0.007 \pm 0.010$ \\
\hline $\mathrm{Hf}$ & - & - & - & $\leq 0.049$ \\
\hline $\mathrm{Hg}$ & $0.65(1)$ & $0.7(5)[22]$ & $0.7(5)[22]$ & $0.031 \pm 0.027$ \\
\hline Ho & - & - & - & $0.001 \pm 0.002$ \\
\hline $\mathrm{Ir}$ & - & - & - & $\leq 0.00054$ \\
\hline $\mathrm{La}$ & - & - & - & $0.034 \pm 0.036$ \\
\hline $\mathrm{Li}$ & - & - & - & $0.064 \pm 0.049$ \\
\hline $\mathrm{Lu}$ & - & - & _ & $<0.00063$ \\
\hline $\mathrm{Mn}$ & $1.0(6)$ & $<0.47(12)[24]$ & $7.3(4)[29]$ & $1.69 \pm 0.84$ \\
\hline Mo & $1.0(2)$ & $<0.19(50)[19]$ & $1.8(2)[20]$ & $0.54 \pm 0.70$ \\
\hline $\mathrm{Nb}$ & - & - & - & $0.013 \pm 0.020$ \\
\hline $\mathrm{Nd}$ & - & - & - & $0.025 \pm 0.034$ \\
\hline $\mathrm{Ni}$ & $<0.47$ (4) & $0.14(4)[30]$ & $4.7(12)[24]$ & $4.1 \pm 3.0$ \\
\hline $\mathrm{Pb}$ & $1.0(11)$ & $0.15(41)[14]$ & $8(4)$ [29] & $1.3 \pm 1.3$ \\
\hline $\mathrm{Pd}$ & - & - & - & $\leq 0.014$ \\
\hline $\operatorname{Pr}$ & - & - & - & $0.006 \pm 0.008$ \\
\hline $\mathrm{Pt}$ & - & - & - & $\leq 0.0029$ \\
\hline $\mathrm{Rb}$ & $34.5(3)$ & 4.7 (9) [21] & $58 \pm 33(4)[29]$ & $14.5 \pm 5.2$ \\
\hline $\operatorname{Re}$ & - & - & - & $\leq 0.0048$ \\
\hline $\mathrm{Sb}$ & $0.42(1)$ & $0.4(10)[22]$ & 0.4 (10) [22] & $0.051 \pm 0.038$ \\
\hline $\mathrm{Sc}$ & - & - & - & $0.013 \pm 0.010$ \\
\hline $\mathrm{Se}$ & $0.625(7)$ & $0.27(129)[15]$ & $1.5(15)[31]$ & $0.54 \pm 0.22$ \\
\hline $\mathrm{Sm}$ & - & - & - & $0.006 \pm 0.008$ \\
\hline $\mathrm{Sn}$ & $3.3(4)$ & $0.66(50)[19]$ & 3.7 (7) [20] & $0.22 \pm 0.27$ \\
\hline $\mathrm{Ta}$ & - & - & - & $\leq 0.010$ \\
\hline $\mathrm{Tb}$ & - & - & - & $0.001 \pm 0.002$ \\
\hline $\mathrm{Te}$ & $164(1)$ & $164(2)[29]$ & $164(2)[29]$ & $<0.003$ \\
\hline Th & - & - & - & $0.008 \pm 0.011$ \\
\hline $\mathrm{Ti}^{*}$ & $7.6(3)$ & $<0.24(50)[19]$ & $26(24)[30]$ & $2.8 \pm 2.9$ \\
\hline $\mathrm{Tl}$ & $0.25(2)$ & 0.0014 (1) [32] & $0.5(1)[20]$ & $0.003 \pm 0.005$ \\
\hline $\mathrm{Tm}$ & - & - & - & $0.0006 \pm 0.0009$ \\
\hline $\mathrm{U}$ & $0.4(1)$ & $0.4(1)[33]$ & $0.4(1)[33]$ & $0.0025 \pm 0.0020$ \\
\hline $\mathrm{Y}$ & $<80(2)$ & $<3.3(12)[24]$ & 89 (12) [24] & $0.036 \pm 0.053$ \\
\hline $\mathrm{Yb}$ & - & - & - & $0.0037 \pm 0.0062$ \\
\hline $\mathrm{Zn}$ & $482(48)$ & $111(-)[34]$ & $2735(10)[28]$ & $281 \pm 230$ \\
\hline $\mathrm{Zr}$ & - & - & - & $0.16 \pm 0.21$ \\
\hline
\end{tabular}

E: Element, M: arithmetic mean, SD: standard deviation, $\mathrm{n}^{\mathrm{a}}$ : number of all references, $\mathrm{n}^{\mathrm{b}}$ : number of samples, -: no data; ${ }^{*}$ Titanium tools were used for sampling and sample preparation. in mass fraction of $\mathrm{Cd}$, Se and $\mathrm{Zn}$ (Table 8, Figure 1). In particular, a strongly pronounced $(p \leq 0.001)$ tendency of

Table 8. Effect of age on mean values $(M \pm S E M)$ trace element mass fraction in pediatric and young adult nonhyperplastic prostate glands.

\begin{tabular}{|c|c|c|c|c|}
\hline $\mathrm{E}$ & $\begin{array}{c}\text { Group } 10-13 \\
\text { year } n=29\end{array}$ & $\begin{array}{c}\text { Group } 214-30 \\
\text { year } \mathrm{n}=21\end{array}$ & $\begin{array}{l}\text { Student's } \\
\text { t-test } p \leq\end{array}$ & $\begin{array}{c}\text { Ratio Group } 2 \\
\text { to group } 1\end{array}$ \\
\hline $\mathrm{Ag}$ & $0.077 \pm 0.011$ & $0.0421 \pm 0.0096$ & 0.020 & 0.549 \\
\hline $\mathrm{Al}$ & $119 \pm 32$ & $37.8 \pm 7.6$ & 0.024 & 0.318 \\
\hline As & $\leq 0.123$ & $\leq 0.012$ & - & - \\
\hline $\mathrm{Au}$ & $0.015 \pm 0.004$ & $0.0040 \pm 0.0011$ & 0.030 & 0.276 \\
\hline B & $9.4 \pm 5.9$ & $1.02 \pm 0.26$ & 0.18 (NS) & 0.109 \\
\hline $\mathrm{Be}$ & $0.005 \pm 0.002$ & $0.0011 \pm 0.0001$ & 0.014 & 0.186 \\
\hline $\mathrm{Bi}$ & $0.032 \pm 0.019$ & $0.0040 \pm 0.0005$ & $0.17(\mathrm{NS})$ & 0.126 \\
\hline $\mathrm{Br}$ & $30.0 \pm 4.5$ & $22.4 \pm 4.0$ & $0.22(\mathrm{NS})$ & 0.747 \\
\hline $\mathrm{Cd}$ & $0.085 \pm 0.013$ & $0.441 \pm 0.072$ & 0.0003 & 5.20 \\
\hline $\mathrm{Ce}$ & $0.073 \pm 0.022$ & $0.024 \pm 0.006$ & 0.045 & 0.330 \\
\hline Co & $0.0440 \pm 0.0061$ & $0.025 \pm 0.002$ & 0.006 & 0.564 \\
\hline $\mathrm{Cr}$ & $0.69 \pm 0.11$ & $0.246 \pm 0.042$ & 0.0006 & 0.357 \\
\hline $\mathrm{Cs}$ & $0.037 \pm 0.009$ & $0.036 \pm 0.003$ & $0.96(\mathrm{NS})$ & 0.986 \\
\hline Dy & $0.011 \pm 0.003$ & $0.0033 \pm 0.0009$ & 0.038 & 0.302 \\
\hline $\mathrm{Er}$ & $0.006 \pm 0.002$ & $0.0019 \pm 0.0006$ & $0.064(\mathrm{NS})$ & 0.310 \\
\hline $\mathrm{Eu}$ & $0.0019 \pm 0.0005$ & $\leq 0.00054$ & - & $\leq 0.287$ \\
\hline $\mathrm{Fe}$ & $120 \pm 16$ & $\overline{72.3} \pm 5.8$ & 0.0099 & 0.60 \\
\hline $\mathrm{Ga}$ & $0.076 \pm 0.015$ & $\leq 0.066$ & - & $\leq 0.868$ \\
\hline $\mathrm{Gd}$ & $0.010 \pm 0.003$ & $0.0028 \pm 0.0008$ & 0.050 & 0.287 \\
\hline $\mathrm{Hf}$ & $0.083 \pm 0.025$ & $\leq 0.013$ & - & $\leq 0.157$ \\
\hline $\mathrm{Hg}$ & $0.035 \pm 0.008$ & $0.028 \pm 0.003$ & 0.92 (NS) & 0.820 \\
\hline Ho & $0.0019 \pm 0.0007$ & $0.0006 \pm 0.0002$ & 0.093 (NS) & 0.314 \\
\hline Ir & $\leq 0.00071$ & $\leq 0.00035$ & - & - \\
\hline $\mathrm{La}$ & $0.049 \pm 0.011$ & $0.017 \pm 0.003$ & 0.017 & 0.351 \\
\hline $\mathrm{Li}$ & $0.085 \pm 0.015$ & $0.042 \pm 0.007$ & 0.022 & 0.499 \\
\hline $\mathrm{Lu}$ & $0.0010 \pm 0.0003$ & $\leq 0.00028$ & - & $\leq 0.292$ \\
\hline $\mathrm{Mn}$ & $1.90 \pm 0.27$ & $1.48 \pm 0.12$ & 0.17 (NS) & 0.779 \\
\hline Mo & $0.79 \pm 0.24$ & $0.279 \pm 0.035$ & 0.050 & 0.353 \\
\hline $\mathrm{Nb}$ & $0.0225 \pm 0.0065$ & $0.0033 \pm 0.0009$ & 0.010 & 0.146 \\
\hline $\mathrm{Nd}$ & $0.038 \pm 0.011$ & $0.0124 \pm 0.0029$ & 0.043 & 0.326 \\
\hline $\mathrm{Ni}$ & $4.50 \pm 1.03$ & $3.65 \pm 0.48$ & $0.46(\mathrm{NS})$ & 0.811 \\
\hline $\mathrm{Pb}$ & $1.81 \pm 0.38$ & $0.75 \pm 0.24$ & 0.027 & 0.414 \\
\hline $\mathrm{Pd}$ & $\leq 0.019$ & $\leq 0.0072$ & - & - \\
\hline $\operatorname{Pr}$ & $0.0085 \pm 0.0026$ & $0.0030 \pm 0.0007$ & $0.061(\mathrm{NS})$ & 0.352 \\
\hline $\mathrm{Pt}$ & $0.0051 \pm 0.0010$ & $\leq 0.00054$ & - & $\leq 0.105$ \\
\hline $\mathrm{Rb}$ & $15.1 \pm 1.2$ & $13.7 \pm 0.79$ & $0.33(\mathrm{NS})$ & 0.907 \\
\hline $\operatorname{Re}$ & $0.0086 \pm 0.0014$ & $\leq 0.00099$ & - & $\leq 0.115$ \\
\hline $\mathrm{Sb}$ & $0.057 \pm 0.010$ & $0.0432 \pm 0.0052$ & $0.22(\mathrm{NS})$ & 0.758 \\
\hline $\mathrm{Sc}$ & $0.0162 \pm 0.0028$ & $0.0087 \pm 0.0012$ & 0.020 & 0.537 \\
\hline $\mathrm{Se}$ & $0.452 \pm 0.040$ & $0.644 \pm 0.045$ & 0.0027 & 1.42 \\
\hline $\mathrm{Sm}$ & $0.0084 \pm 0.0027$ & $0.0025 \pm 0.0007$ & 0.050 & 0.293 \\
\hline $\mathrm{Sn}$ & $0.342 \pm 0.082$ & $0.096 \pm 0.025$ & 0.011 & 0.281 \\
\hline $\mathrm{Ta}$ & $\leq 0.016$ & $\leq 0.0044$ & - & - \\
\hline $\mathrm{Tb}$ & $0.0019 \pm 0.0007$ & $0.0004 \pm 0.0001$ & $0.063(\mathrm{NS})$ & 0.219 \\
\hline $\mathrm{Te}$ & $<0.003$ & $<0.003$ & - & - \\
\hline Th & $0.0128 \pm 0.0034$ & $0.0021 \pm 0.0006$ & 0.0083 & 0.164 \\
\hline $\mathrm{Ti}^{*}$ & $4.14 \pm 0.87$ & $1.35 \pm 0.25$ & 0.0073 & 0.326 \\
\hline $\mathrm{Tl}$ & $0.0049 \pm 0.0016$ & $0.0014 \pm 0.0001$ & 0.050 & 0.286 \\
\hline $\mathrm{Tm}$ & $0.0010 \pm 0.0003$ & $0.0003 \pm 0.0001$ & 0.048 & 0.308 \\
\hline $\mathrm{U}$ & $0.0034 \pm 0.0007$ & $0.0016 \pm 0.0003$ & 0.037 & 0.485 \\
\hline $\mathrm{Y}$ & $0.055 \pm 0.018$ & $0.0159 \pm 0.0055$ & 0.055 & 0.289 \\
\hline $\mathrm{Yb}$ & $0.0056 \pm 0.0022$ & $0.0018 \pm 0.0006$ & $0.11(\mathrm{NS})$ & 0.313 \\
\hline $\mathrm{Zn}$ & $155 \pm 31$ & $456 \pm 41$ & 0.000001 & 2.94 \\
\hline $\mathrm{Zr}$ & $0.247 \pm 0.063$ & $0.055 \pm 0.020$ & 0.0097 & 0.223 \\
\hline
\end{tabular}

E: Element, M: arithmetic mean, SEM: standard error of mean, NS: not significant. ${ }^{*}$ Titanium tools were used for sampling and sample preparation. 
Al
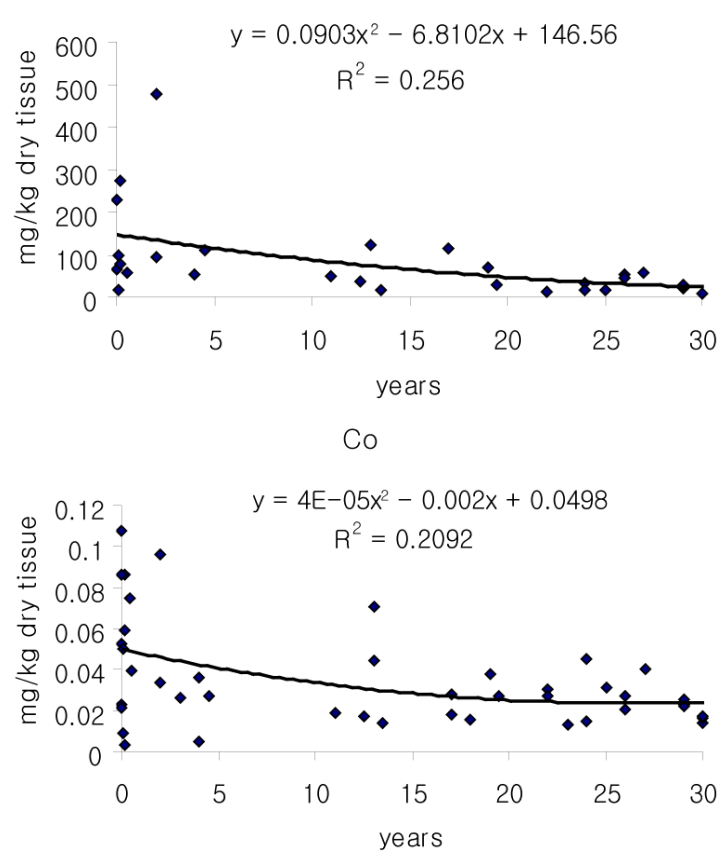

$\mathrm{Hg}$

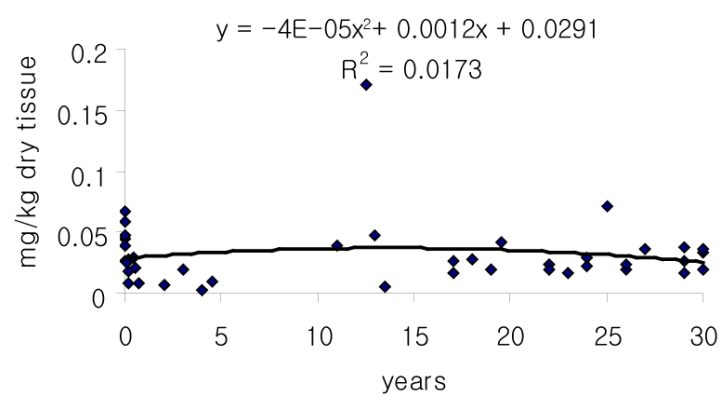

$\mathrm{Se}$

$y=-0.0001 x^{2}+0.0134 x+0.4095$

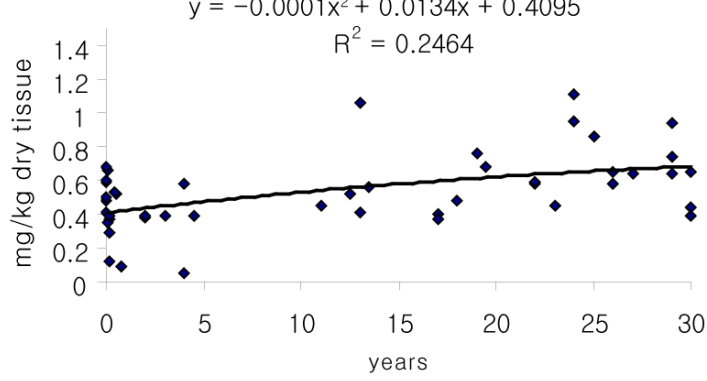

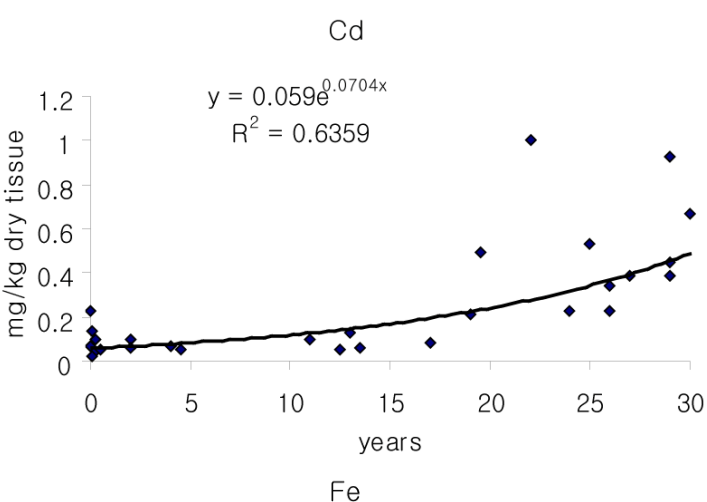

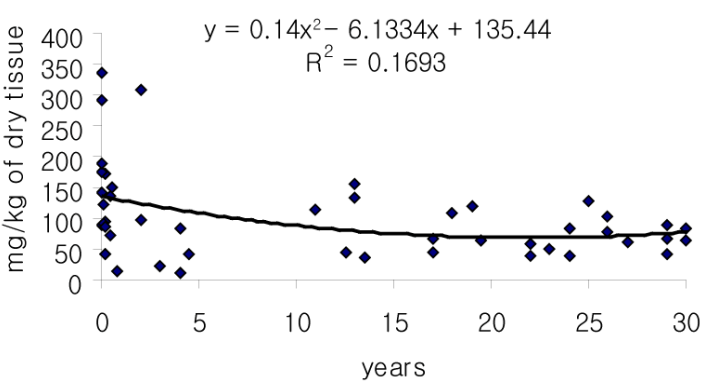

$\mathrm{Pb}$

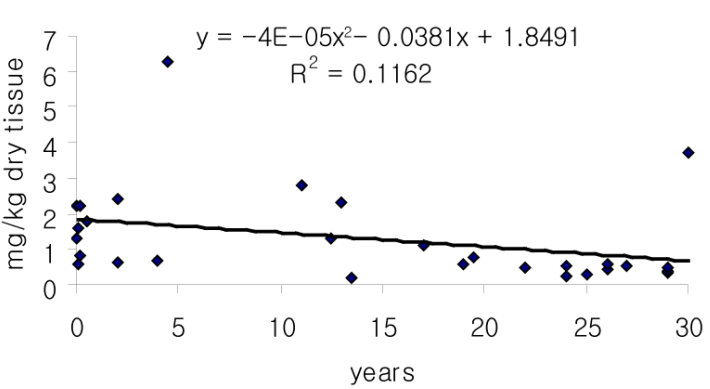

years

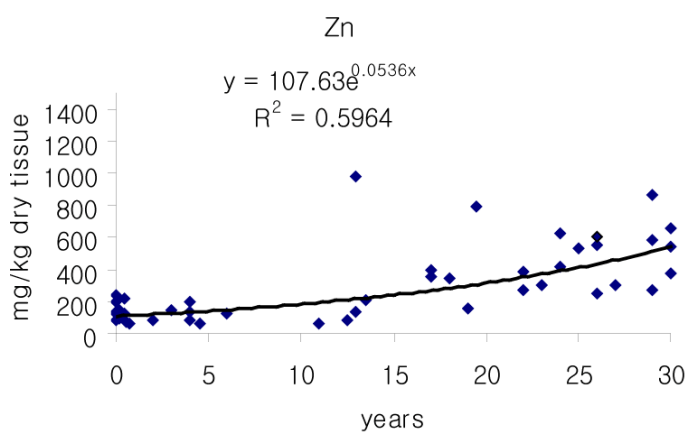

Figure 1. Individual data sets for the $\mathrm{Al}, \mathrm{Cd}, \mathrm{Co}, \mathrm{Fe}, \mathrm{Hg}, \mathrm{Pb}, \mathrm{Se}$, and $\mathrm{Zn}$ mass fraction in the nonhyperplastic prostate gland of males between ages 0 - 30 years and their trend lines with equations of best fit.

age-related increase in $\mathrm{Cd}$ and $\mathrm{Zn}$ mass fraction was observed in prostate (Table 8). For example, in prostate of adolescent and young adult (group 2), $\mathrm{Cd}$ and $\mathrm{Zn}$ mass fraction was 5.2 and 2.9 times, respectively, greater than in prostate of children before puberty (group 1). An increase of $\mathrm{Cd}$ and $\mathrm{Zn}$ mass fraction in the prostate tissue with age from the time of birth up to 30 years is more ideally fitted by an exponential law than by a linear, polynomial, logarithmic or power law (Figure 1). An increase of Se mass fraction is more ideally fitted by a polynomial law (Figure 1).

This work result for age-dependence of $\mathrm{Fe}$ and $\mathrm{Zn}$ mass fraction is in accordance with earlier findings $[2,3]$. For example, Heinzsch et al. [2] found that $\mathrm{Zn}$ mass fraction in normal prostate was higher after the age of 10 (age group 11 - 30 years) than before by approximately 
1.7 times, and that Fe mass fraction in prostate gland of males aged 11 - 30 years was lower than in infant prostate by approximately two times. In accordance with Leissner et al. [3] the mean $\mathrm{Zn}$ mass fraction in prostate tissue of 20 - 29 years old men was 4.9 times greater than in prostate of 0 - 5 years old subjects.

\subsection{Comparison with Trace Element Mass Fractions in Liver of Reference Man}

For pre-puberty the mean obtained for the $\mathrm{Zn}$ mass fraction in prostate tissue is lower than the mean $\mathrm{Zn}$ mass fraction in liver of reference man [36,37], but during puberty and postpuberty it is approximately three times higher (Table 9). This implies that the $\mathrm{Zn}$ mass fraction in prostate tissue is associated with the male androgen status. Also for post-puberty the means obtained for the $\mathrm{Al}, \mathrm{Au}, \mathrm{B}, \mathrm{Br}, \mathrm{Cr}, \mathrm{Ga}, \mathrm{Li}$, and Ni mass fractions in prostate tissue are higher than their mean values in the liver of reference man. However, mass fractions of these elements in prostate gland of young adult males are lower than in pediatric prostate glands. This implies that the Al, $\mathrm{Au}, \mathrm{B}, \mathrm{Br}, \mathrm{Cr}, \mathrm{Ga}, \mathrm{Li}$, and $\mathrm{Ni}$ mass fractions are an androgen-independent parameter and that these elements are not directly linked to any reproductive function of the prostate.

\section{Conclusions}

Both INAA-LLR and ICP-MS methods are an adequate analytical tool for the precise determination of trace element mass fraction in the tissue samples of pediatric and nonhyperplastic young adult prostate glands. The combination of two methods allowed determinations of mean mass fraction of $\mathrm{Ag}, \mathrm{Al}, \mathrm{Au}, \mathrm{B}, \mathrm{Be}, \mathrm{Bi}, \mathrm{Br}, \mathrm{Cd}, \mathrm{Ce}, \mathrm{Co}$, $\mathrm{Cr}$, Cs, Dy, Er, Fe, Gd, Hg, Ho, La, Li, Mn, Mo, Nb, Nd, $\mathrm{Ni}, \mathrm{Pb}, \mathrm{Pr}, \mathrm{Rb}, \mathrm{Sb}, \mathrm{Sc}, \mathrm{Se}, \mathrm{Sm}, \mathrm{Sn}, \mathrm{Tb}, \mathrm{Th}, \mathrm{Ti}, \mathrm{Tl}, \mathrm{Tm}, \mathrm{U}$, $\mathrm{Y}, \mathrm{Yb}, \mathrm{Zn}$, and $\mathrm{Zr}$ (43 elements) and the upper limit of mean for As, Eu, Ga, Hf, Ir, Lu, Pd, Pt, Re, and Ta (10 elements). Mean values $(\mathrm{M} \pm \mathrm{SEM})$ for mass fraction (milligram per kilogram, on dry-weight basis) of trace elements in the nonhyperplastic prostate gland of males in the age ranges 0 - 30 years obtained in this work were: Ag 0.062 $\pm 0.008, \mathrm{Al} 80 \pm 18$, Au $0.0092 \pm 0.0024$, B 5.9 \pm 3.5 , Be $0.0034 \pm 0.0009$, Bi $0.018 \pm 0.010$, Br $26 \pm 3$, Cd 0.26 \pm 0.05 , Ce 0.049 \pm 0.012 , Co $0.035 \pm 0.004, \mathrm{Cr}$ $0.49 \pm 0.07$, Cs $0.036 \pm 0.005$, Dy $0.0072 \pm 0.0018, \mathrm{Er}$ $0.0040 \pm 0.0011, \mathrm{Fe} 100 \pm 10, \mathrm{Gd} 0.0065 \pm 0.0018, \mathrm{Hg}$ $0.031 \pm 0.004$, Ho $0.0013 \pm 0.0004$, La $0.034 \pm 0.007, \mathrm{Li}$ $0.064 \pm 0.009$, Mn $1.69 \pm 0.15$, Mo $0.54 \pm 0.13, \mathrm{Nb}$ $0.013 \pm 0.004, \mathrm{Nd} 0.025 \pm 0.006, \mathrm{Ni} 4.1 \pm 0.6, \mathrm{~Pb} 1.3 \pm$ $0.2, \operatorname{Pr} 0.0058 \pm 0.0015, \mathrm{Rb} 14.5 \pm 0.8, \mathrm{Sb} 0.051 \pm 0.006$, Sc $0.013 \pm 0.002$, Se $0.54 \pm 0.03$, Sm $0.0055 \pm 0.0015$, Sn $0.22 \pm 0.05$, Tb $0.0012 \pm 0.0004$, Th $0.0076 \pm 0.0020$, Ti $2.8 \pm 0.5$, Tl $0.0032 \pm 0.0009$, Tm $0.00064 \pm 0.00017$,
Table 9. The differences between the means of trace element mass fraction in the prostate tissue and in liver of Reference Man (in milligrams per kilogram dry-mass basis).

\begin{tabular}{|c|c|c|c|c|c|}
\hline \multirow{3}{*}{$\mathrm{E}$} & \multicolumn{2}{|c|}{$\begin{array}{l}\text { This work } \\
\text { result for prostate }\end{array}$} & \multirow{2}{*}{$\begin{array}{c}\text { Median of means } \\
\text { for Reference } \\
\text { Man }[36,37] \\
\text { Liver }\end{array}$} & \multicolumn{2}{|c|}{$\begin{array}{c}\text { Ratios } \\
p \text { (t-test) }\end{array}$} \\
\hline & $\begin{array}{l}\text { Before } \\
\text { puberty }\end{array}$ & $\begin{array}{c}\text { After } \\
\text { puberty }\end{array}$ & & $\begin{array}{l}\text { Before } \\
\text { puberty }\end{array}$ & $\begin{array}{c}\text { After } \\
\text { puberty }\end{array}$ \\
\hline & $\mathrm{P}_{1}$ & $\mathrm{P}_{2}$ & $\mathrm{~L}$ & $\mathrm{P}_{1} / \mathrm{L}$ & $\mathrm{P}_{2} / \mathrm{L}$ \\
\hline $\mathrm{Ag}$ & 0.0767 & 0.0421 & 0.069 & 1.11 & 0.61 \\
\hline $\mathrm{Al}$ & 119 & 37.8 & 0.0040 & 29750 & 9450 \\
\hline As & $\leq 0.123$ & $\leq 0.012$ & 0.034 & $\leq 3.6$ & $\leq 0.35$ \\
\hline $\mathrm{Au}$ & 0.0145 & 0.0040 & 0.00018 & 80.6 & 22.2 \\
\hline B & 9.4 & 1.02 & $<0.36$ & $>26.1$ & $>2.8$ \\
\hline $\mathrm{Be}$ & 0.0059 & 0.00110 & - & - & - \\
\hline $\mathrm{Bi}$ & 0.032 & 0.00404 & 0.014 & 2.28 & 0.29 \\
\hline $\mathrm{Br}$ & 30.0 & 22.4 & 5.2 & 5.77 & 4.31 \\
\hline $\mathrm{Cd}$ & 0.085 & 0.441 & 4.3 & 0.020 & 0.103 \\
\hline $\mathrm{Ce}$ & 0.073 & 0.0241 & 0.21 & 0.35 & 0.115 \\
\hline $\mathrm{Co}$ & 0.0440 & 0.0248 & 0.31 & 0.14 & 0.088 \\
\hline $\mathrm{Cr}$ & 0.69 & 0.246 & 0.097 & 7.11 & 2.54 \\
\hline Cs & 0.0365 & 0.0360 & 0.045 & 0.81 & 0.80 \\
\hline Dy & 0.0108 & 0.00326 & - & - & - \\
\hline $\mathrm{Er}$ & 0.0060 & 0.00186 & - & - & - \\
\hline $\mathrm{Eu}$ & 0.00188 & $\leq 0.00054$ & - & - & - \\
\hline $\mathrm{Fe}$ & 120 & 72.3 & 1000 & 0.12 & 0.072 \\
\hline $\mathrm{Ga}$ & 0.076 & $\leq 0.066$ & 0.0024 & 31.7 & $\leq 27.5$ \\
\hline Gd & 0.0099 & 0.00284 & - & - & - \\
\hline Hf & 0.083 & $\leq 0.013$ & - & - & - \\
\hline $\mathrm{Hg}$ & 0.0345 & 0.0283 & 0.31 & 0.11 & 0.091 \\
\hline Ho & 0.00191 & 0.00060 & - & - & - \\
\hline Ir & $\leq 0.00071$ & $\leq 0.00035$ & - & - & - \\
\hline $\mathrm{La}$ & 0.049 & 0.0172 & 0.28 & 0.18 & 0.061 \\
\hline $\mathrm{Li}$ & 0.085 & 0.0424 & $<0.0036$ & $>23.6$ & $>11.8$ \\
\hline $\mathrm{Lu}$ & 0.00096 & $\leq 0.00028$ & - & - & - \\
\hline Mn & 1.90 & 1.48 & 5.4 & 0.35 & 0.27 \\
\hline Mo & 0.79 & 0.279 & 2.1 & 0.38 & 0.13 \\
\hline $\mathrm{Nb}$ & 0.0225 & 0.00329 & 0.14 & 0.16 & 0.024 \\
\hline $\mathrm{Nd}$ & 0.038 & 0.0124 & - & - & - \\
\hline $\mathrm{Ni}$ & 4.50 & 3.65 & 0.10 & 45.0 & 36.5 \\
\hline $\mathrm{Pb}$ & 1.81 & 0.75 & 1.6 & 1.13 & 0.47 \\
\hline $\mathrm{Pd}$ & $\leq 0.019$ & $\leq 0.0072$ & - & - & - \\
\hline $\operatorname{Pr}$ & 0.0085 & 0.00299 & - & - & - \\
\hline $\mathrm{Pt}$ & 0.00513 & $\leq 0.00054$ & 0.11 & 0.047 & $\leq 0.0049$ \\
\hline $\mathrm{Rb}$ & 15.1 & 13.7 & 17.2 & 0.88 & 0.80 \\
\hline $\mathrm{Re}$ & 0.0086 & $\leq 0.00099$ & - & - & - \\
\hline $\mathrm{Sb}$ & 0.057 & 0.0432 & 0.052 & 1.10 & 0.83 \\
\hline $\mathrm{Sc}$ & 0.0162 & 0.0087 & 0.018 & 0.90 & 0.48 \\
\hline $\mathrm{Se}$ & 0.452 & 0.644 & 1.12 & 0.40 & 0.58 \\
\hline $\mathrm{Sm}$ & 0.0084 & 0.00246 & - & - & - \\
\hline $\mathrm{Sn}$ & 0.342 & 0.096 & 1.90 & 0.18 & 0.051 \\
\hline $\mathrm{Ta}$ & $\leq 0.016$ & $\leq 0.0044$ & - & - & - \\
\hline $\mathrm{Tb}$ & 0.00187 & 0.00041 & - & - & - \\
\hline $\mathrm{Te}$ & $<0.003$ & $<0.003$ & - & - & - \\
\hline $\mathrm{Th}$ & 0.0128 & 0.00210 & - & - & - \\
\hline $\mathrm{Ti}^{*}$ & 4.14 & 1.35 & - & - & - \\
\hline $\mathrm{Tl}$ & 0.0049 & 0.00140 & 0.19 & 0.026 & 0.0074 \\
\hline $\mathrm{Tm}$ & 0.00097 & 0.000299 & - & - & - \\
\hline $\mathrm{U}$ & 0.00338 & 0.00164 & 0.0010 & 3.38 & 1.64 \\
\hline $\mathrm{Y}$ & 0.055 & 0.0159 & - & - & - \\
\hline $\mathrm{Yb}$ & 0.0056 & 0.00175 & - & - & - \\
\hline $\mathrm{Zn}$ & 155 & 456 & 172 & 0.90 & 2.65 \\
\hline $\mathrm{Zr}$ & 0.247 & 0.055 & 0.103 & 2.40 & 0.53 \\
\hline
\end{tabular}

E: Element, Values in bold have ratio magnitude $>2.0$. 
$\mathrm{U} 0.0025 \pm 0.0004, \mathrm{Y} 0.036 \pm 0.010, \mathrm{Yb} 0.0037 \pm 0.0012$, $\mathrm{Zn} 281 \pm 32$, and $\mathrm{Zr} 0.16 \pm 0.04$. The upper limit of mean mass fraction of As, Eu, Ga, Hf, Ir, Lu, Pd, Pt, Re, and Ta were: $\mathrm{As} \leq 0.069, \mathrm{Eu} \leq 0.0012, \mathrm{Ga} \leq 0.071, \mathrm{Hf} \leq$ 0.049, Ir $\leq 0.00054, \mathrm{Lu} \leq 0.00063, \mathrm{Pd} \leq 0.014, \mathrm{Pt} \leq$ $0.0029, \mathrm{Re} \leq 0.0048$, and $\mathrm{Ta} \leq 0.010$. In all prostate samples, the content of Te was under the detection limit $(<0.003)$.

This work result reveals that there is a significant tendency of increase in $\mathrm{Cd}$, Se and $\mathrm{Zn}$ mass fraction in the prostate tissue of healthy individuals with age from the time of birth up to 30 years. It means that $\mathrm{Cd}$, Se and $\mathrm{Zn}$ mass fractions in prostate tissue are the androgen-dependent parameters. Our finding of positive correlation between the prostatic $\mathrm{Zn}$ and Se mass fractions indicates that there is a special relationship of $\mathrm{Zn}$ with Se-containing compounds in the prostate. It was also shown that high levels of $\mathrm{Al}, \mathrm{Au}, \mathrm{B}, \mathrm{Br}, \mathrm{Cr}, \mathrm{Ga}, \mathrm{Li}$, and $\mathrm{Ni}$ mass fraction in prostate tissue do not indicate a direct involvement of these elements in the reproductive function of prostate.

All the deceased were citizens of Moscow. None of those who died a sudden death had suffered from any systematic or chronic disorders before. The normal state of prostates was confirmed by morphological study. Thus, our data for mass fractions of 54 trace element mass fractions in intact prostate of two groups reflect the infant, childhood, and peripubertal periods (group 1) and adolescent and young adult periods (group 2) may serve as indicative normal values for urban population of the Russian Central European region.

\section{Acknowledgements}

The authors are grateful to the late Prof. A.A. Zhavoronkov, Institute of Human Morphology, Russian Academy of Medical Sciences, Moscow, for supplying prostate specimens. We are also grateful to Dr. Karandaschev V., Dr. Nosenko S., and Moskvina I., Institute of Microelectronics Technology and High Purity Materials, Chernogolovka, Russia, for their help in ICP-MS analysis.

\section{REFERENCES}

[1] S. Zaichick, V. Zaichick, S. Nosenko and I. Moskvina, "Mass Fractions of 52 Trace Elements and Zinc Trace Element Content Ratios in Intact Human Prostates Investigated by Inductively Coupled Plasma Mass Spectrometry," Biological Trace Element Research, Vol. 149, No. 2, 2012, pp. 171-183. http://dx.doi.org/10.1007/s12011-012-9427-4

[2] E. Hienzsch, H.-J. Schneider and M. Anke, "Vergleichende Untersuchungen zum Mengen- und Spurenelementgehalt der Normalen Prostata, des Prostataadenoms und des Prostatakarzinoms," Zeitschrift für Urologie und Nephrologie, Vol. 63, No. 7, 1970, pp. 543-546.
[3] K. M. Leissner, B. Fielkegard and L.-E. Tisell, "Concentration and Content of Zinc in Human Prostate," Investigative Urology, Vol. 18, No. 1, 1980, pp. 32-35.

[4] V. Zaichick, "INAA and EDXRF Applications in the Age Dynamics Assessment of Zn Content and Distribution in the Normal Human Prostate," Journal of Radioanalytical and Nuclear Chemistry, Vol. 262, No. 1, 2004, pp. 229234. http://dx.doi.org/10.1023/B:JRNC.0000040879.45030.4f

[5] S. Zaichick and V. Zaichick, "Relations of Morphometric Parameters to Zinc Content in Paediatric and Nonhyperplastic Young Adult Prostate Glands," Andrology, Vol. 1, No. 1, 2013, pp. 139-146.

http://dx.doi.org/10.1111/j.2047-2927.2012.00005.x

[6] S. Zaichick and V. Zaichick, "INAA Application in the Age Dynamics Assessment of $\mathrm{Br}, \mathrm{Ca}, \mathrm{Cl}, \mathrm{K}, \mathrm{Mg}, \mathrm{Mn}$, and $\mathrm{Na}$ Content in the Normal Human Prostate," Journal of Radioanalytical and Nuclear Chemistry, Vol. 288, No. 1, 2011, pp. 197-202. http://dx.doi.org/10.1007/s10967-010-0927-4

[7] S. Zaichick and V. Zaichick, "The Effect of Age on Ag, $\mathrm{Co}, \mathrm{Cr}, \mathrm{Fe}, \mathrm{Hg}, \mathrm{Sb}, \mathrm{Sc}, \mathrm{Se}$, and $\mathrm{Zn}$ Contents in Intact Human Prostate Investigated by Neutron Activation Analysis," Applied Radiation and Isotopes, Vol. 69, No. 6, 2011, pp. 827-833.

http://dx.doi.org/10.1016/j.apradiso.2011.02.010

[8] V. Zaichick, S, Nosenko and I. Moskvina, "The Effect of Age on 12 Chemical Element Contents in Intact Prostate of Adult Men Investigated by Inductively Coupled Plasma Atomic Emission Spectrometry," Biological Trace Element Research, Vol. 147, No. 1, 2012, pp. 49-58. http://dx.doi.org/10.1007/s12011-011-9294-4

[9] L.-E. Tisell, B. Fjelkegard and K. H. Leissner, "Zinc Concentration and Content of the Dorsal, Lateral and Medial Prostatic Lobes and of Periurethral Adenomas in Man," Journal of Urology, Vol. 128, No. 2, 1982, pp. 403-405.

[10] A. Feustel and R. Wennrich, "Zinc and Cadmium in Cell Fractions of Prostatic Cancer Tissue of Different Histological Grading in Comparison to BPH and Normal Prostate," Urological Research, Vol. 12, No. 2, 1984, pp. 147 150. http://dx.doi.org/10.1007/BF00257182

[11] B. E. Saltzman, S. B. Gross, D. W. Yeager, B. G. Meiners and P. S. Gartside, "Total Body Burdens and Tissue Concentrations of Lead, Cadmium, Copper, Zinc, and Ash in 55 Human Cadavers," Environmental Research, Vol. 52, No. 2, 1990, pp. 126-145. http://dx.doi.org/10.1016/S0013-9351(05)80248-8

[12] L. Picurelli, P. V. Olcina, M. D. Roig and J. Ferrer, "Determination of $\mathrm{Fe}, \mathrm{Mg}, \mathrm{Cu}$, and $\mathrm{Zn}$ in Normal and Pathological Prostatic Tissue," Actas Urologicas Españolas, Vol. 15, No. 4, 1991, pp. 344-350.

[13] L. Picurelli, P. V. Olcina, M. D. Roig, S. Günthner and J. Ferrer, "Determination and Relationship of the Copper and Zinc Concentrations in Normal and Pathologic Prostatic Tissue," Trace Elements in Medicine, Vol. 8, No. 3, 1991, pp. 131-137.

[14] N. B. Oldereid, Y. Thomassen, A. Attramadal, B. Olaisen and K. Purvis, "Concentrations of Lead, Cadmium and Zinc in the Tissues of Reproductive Organs of Men," 
Journal of Reproduction and Fertility, Vol. 99, No. 2, 1993, pp. 421-425.

http://dx.doi.org/10.1530/jrf.0.0990421

[15] J. Schöpfer, G. Drasch and G. N. Schrauzer, "Selenium and Cadmium Levels and Ratios in Prostates, Livers, and Kidneys of Nonsmokers and Smokers," Biological Trace Element Research, Vol. 134, No. 2, 2010, pp. 180-187. http://dx.doi.org/10.1007/s12011-010-8636-y

[16] V. Zaichick, "Sampling, Sample Storage and Preparation of Biomaterials for INAA in Clinical Medicine, Occupational and Environmental Health," In: Harmonization of health-Related Environmental Measurements Using $\mathrm{Nu}$ clear and Isotopic Techniques, IAEA, Vienna, 1997, pp. 123-133.

[17] V. Zaichick, "Losses of Chemical Elements in Biological Samples under the Dry Ashing Process," Trace Elements in Medicine (Moscow), Vol. 5, No. 3, 2004, pp. 17-22.

[18] A. M. Korelo and V. Zaichick, "Software to Optimize the Multielement INAA of Medical and Environmental Samples," In: Activation Analysis in Environment Protection, Join Institute of Nuclear Research, Dubna, 1993, pp. 326332.

[19] I. H. Tipton and M. J. Cook, "Trace Elements in Human Tissue. Part II. Adult Subjects from the United States," Health Physics, Vol. 9, No. 2, 1963, pp. 103-145. http://dx.doi.org/10.1097/00004032-196302000-00002

[20] J. H. Tipton, R. L. Steiner, W. D. Foland, J. Mueller and M. Stanley, USAEC-ORNL-Report-CF-54-12-66, 1954.

[21] S. R. Stitch, "Trace Elements in Human Tissue. I. A Semi-Quantitative Spectrographic Survey," Biochemical Journal, Vol. 67, No. 1, 1957, pp. 97-103.

[22] K. Liebscher and H. Smith, "Essential and Nonessential Trace Elements. A Method of Determining Whether an Element Is Essential or Nonessential in Human Tissue," Archives of Environmental Health, Vol. 17, No. 6, 1968, pp. 882-891. http://dx.doi.org/10.1080/00039896.1968.10665346

[23] H. Kubo, S. Hashimoto, A. Ishibashi, R. Chiba and H. Yokota, "Simultaneous Determinations of $\mathrm{Fe}, \mathrm{Cu}, \mathrm{Zn}$, and Br Concentrations in Human Tissue Sections," Medical Physics, Vol. 3, No. 4, 1976, pp. 204-209. http://dx.doi.org/10.1118/1.594233

[24] A. Forssen, "Inorganic Elements in the Human Body. I. Occurrence of $\mathrm{Ba}, \mathrm{Br}, \mathrm{Ca}, \mathrm{Cd}, \mathrm{Cs}, \mathrm{Cu}, \mathrm{K}, \mathrm{Mn}, \mathrm{Ni}, \mathrm{Sn}, \mathrm{Sr}$, $\mathrm{Y}$ and $\mathrm{Zn}$ in the Human Body," Annales Medicinae Experimentalis et Biologie (Finland), Vol. 50, No. 3, 1972, pp. 99-162.

[25] J. O. Ogunlewe and D. N. Osegbe, "Zinc and Cadmium Concentrations in Indigenous Blacks with Normal, Hypertrophic, and Malignant Prostate," Cancer, Vol. 63, No. 7, 1989, pp. 1388-1392.

http://dx.doi.org/10.1002/1097-0142(19890401)63:7<138 8::AID-CNCR2820630725>3.0.CO;2-M

[26] N. Yamagata, "The Concentration of Common Cesium and Rubidium in Human Body," Journal of Radiation Research, Vol. 3, No. 1, 1962, pp. 9-30.

http://dx.doi.org/10.1269/jrr.3.9

[27] H. Sangen, "The Influence of the Trace Metals upon the Aconitase Activity in Human Prostate Glands," Japanese Journal of Urology, Vol. 58, No. 11, 1967, pp. 11461159.

[28] A. Jafa, N. M. Mahendra, A. R. Chowdhury and V. P. Kamboj, "Trace Elements in Prostatic Tissue and Plasma in Prostatic Diseases of Man," Indian Journal of Cancer, Vol. 17, No. 1, 1980, pp. 34-37.

[29] S. D. Soman, K. T. Joseph, S. J. Raut, G. D. Mulay, M. Parameswaran and V. K. Pandey, "Studies of Major and Trace Element Content in Human Tissues," Health Physics, Vol. 19, No. 5, 1970, pp. 641-656. http://dx.doi.org/10.1097/00004032-197011000-00006

[30] H. J. Koch and E. R. Smith, "The Determination of Copper and Zinc in Normal and Pathologic Human Thyroid Tissue," Journal of Clinical Endocrinology, Vol. 16, No. 1, 1956, pp. 123-129. http://dx.doi.org/10.1210/jcem-16-1-123

[31] A. G. Sarafanov, T. I. Todorov, A. Kajdacsy-Balla, M. A. Gray, V. Macias and J. A. Centeno, "Analysis of Iron, Zinc, Selenium and Cadmium in Paraffin-Embedded Prostate Tissue Specimens Using Inductively Coupled Plasma Mass-Spectrometry," Journal of Trace Elements in Medicine and Biology, Vol. 22, No. 4, 2008, pp. 305-314. http://dx.doi.org/10.1016/i.jtemb.2008.03.010

[32] E. Weinig and P. Zink, "Über die Quantitative Massenspektrometrische Bestimmung des Normalen ThalliumGeehalts Inmenschlichen Organismus," Archive für Toxikologie, Vol. 22, No. 4, 1967, pp. 255-274.

[33] B. Höffken and J. G. Rausch-Stroomann, "A Study of the Metabolism of Zinc Its Metalloenzymes in Diabetes Mellitus," Zeitschrift für Klinische Chemie und Klinische Biochemie, Vol. 7, No. 1, 1969, pp. 4-7.

[34] L. R. Anspaugh, W. L. Robinson, W. H. Martin and O. A. Lowe, "Compilation of Published Information on Elemental Concentrations in Human Organs in Both Normal and Diseased States," No. UCRL-51013Pt. 1971-1973. 1973, pp.1-4.

[35] F. Györkey, K.-W. Min, J. A. Huff and P. Györkey, “Zinc and Magnesium in Human Prostate Gland: Normal, Hyperplastic, and Neoplastic," Cancer Research, Vol. 27, No. 8, 1967, pp. 1349-1353.

[36] G. V. Iyengar, "Reevaluation of the Trace Element Content in Reference Men," Radiation Physics and Chemistry, Vol. 51, No. 4-6, 1998, pp. 545-560. http://dx.doi.org/10.1016/S0969-806X(97)00202-8

[37] G. V. Iyengar, W. E. Kollmer and H. G. M. Bowen, "The Elemental Composition of Human Tissues and Body Fluids. A Compilation of Values for Adults," Verlag Chemie, Weinheim, 1978. 